\title{
A review of the Birimian Supergroup- and Tarkwaian Group-hosted gold deposits of Ghana
}

\author{
Albertus J. B. Smith ${ }^{1,2^{*}}$, George Henry ${ }^{1,2}$ and Susan Frost-Killian ${ }^{3}$ \\ ${ }^{1}$ DST-NRF Centre of Excellence for Integrated Mineral and Energy Resource Analysis, Department of Geology, University of Johannesburg, \\ Auckland Park, 2006, South Africa. *Corresponding author e-mail address: bertuss@uj.ac.za \\ ${ }^{2}$ Palaeoproterozoic Mineralisation Research Group, Department of Geology, University of Johannesburg, Auckland Park, 2006, South Africa \\ ${ }^{3}$ The MSA Group, 20B Rothesay Avenue, Craighall Park, 2196, South Africa
}

DOI: 10.18814/epiiugs/2016/v39i2/95775

Ghana is the largest producer of gold in West Africa, a region with over 2,500 years of history with regards to gold production and trade. Modern exploration for and mining of gold in Ghana dates from 1874 with the establishment of the British Gold Coast Colony, which was followed in 1957 by the independence of Ghana and increased gold production since the early 1980s through Ghana's Economic Recovery Plan. At the time of writing, gold production (108.2 tonnes or 3.48 million ounces [Moz] in 2014) accounted for approximately one-third of Ghana's export revenues, with $36 \%$ of gold production coming from small-scale mining.

The majority of the gold occurs in two styles of mineralisation, namely mesothermal quartz vein-hosted and associated gold in metavolcanics and metasediments and modified palaeoplacer gold in conglomerates. These styles of mineralisation occur in the Palaeoproterozoic Birimian Supergroup and Tarkwaian Group that make up Ghana's mainly southwest to northeast trending Birimian belts. Significant gold resources also occur as hydrothermal mineralisation in basement-type granitoids which show some geological association with the Birimian Supergroup-hosted mesothermal mineralisation. The majority of the gold mineralisation is believed to have formed between approximately 2.15 and 2.06 Ga during the Eburnean orogeny.

The mesothermal quartz vein gold mineralisation is usually confined to tectonic corridors within the Birimian belts and is strongly associated with shear zones and fault systems. The quartz veins show multiple stages of formation and are steeply dipping, with the gold mineralisation occurring either as free gold within fractures in the veins or as invisible gold within disseminated sulphides in the host rocks surrounding the veins. The vein- and sulphide-hosted gold is strongly associated with deformational fabrics formed by the Eburnean extensional and compressional events, respectively, suggesting that disseminated sulphide mineralisation predates quartz vein-hosted mineralisation. The fluid from which the gold precipitated is believed to have been of metamorphic origin and carbon dioxide $\left(\mathrm{CO}_{2}\right)$ dominated, with lesser water $\left(\mathrm{H}_{2} \mathrm{O}\right)$ and nitrogen $\left(\mathrm{N}_{2}\right)$ and minor methane $\left(\mathrm{CH}_{4}\right)$. Gold precipitation was probably caused by decrease in pressure, temperature and $\mathrm{CO}_{2}-\mathrm{H}_{2} \mathrm{O}$ immiscibility, at depths of between 7 and $11 \mathrm{~km}$.

The palaeoplacer gold mineralisation shows some hydrothermal modification and occurs mostly within the conglomerates and to a lesser extent within the interbedded quartzite of the Banket Series of the Tarkwaian Group. The gold occurs as free gold in the matrix of the conglomerates and as intergrowths and overgrowths on and inclusions in, other heavy mineral grains. Based on strong evidence for palaeoplacer mineralisation, the gold was likely deposited with the conglomerates in alluvial fans and braided tributary channels. Because the Eburnean compressional event associated with the Birimian Supergroup-hosted mesothermal gold mineralisation also overprinted the gold-bearing Banket conglomerates, the former gold occurrences could not have acted as the source for the palaeoplacer gold.

Hydrothermal gold mineralisation occurs in the Palaeoproterozoic belts and basin granitoids that intrude the Birimian belts, as well as in the sedimentary basins occurring between the belts. Gold mineralisation within the granitoids occurs as micro-inclusions in sulphides in small, steeply dipping stockworks and as sulphide 
disseminations concordant with regional faults and shears. A gold-bearing fluid similar to that for the Birimian Supergroup-hosted quartz vein gold mineralisation, but with a larger $\mathrm{H}_{2} \mathrm{O}$ component, is proposed to have formed the granitoid-hosted gold mineralisation.

\section{Introduction}

The mining and trade of gold in West Africa has a long history, possibly dating as far back as $500 \mathrm{BC}$ (Ellis, 1893; Ward, 1967). Of all the countries producing gold in West Africa, the largest and most prominent past and present producing mines are located in Ghana (which has more that 1,500 tonnes of cumulative gold production; Eisenlohr, 1992; Oberthür et al., 1995). Before the discovery of the Witwatersrand gold reefs in South Africa in 1886, Ghana was the top gold producer on the African continent (Pigois et al., 2003). Today, mining contributes more than one-third of Ghana's export revenues and gold contributes $95 \%$ of this mining revenue (2.63 Moz and 3.48 Moz gold produced in 2013 and 2014 respectively; Ghana Chamber of Mines, 2014; GCM-ICMM, 2015).

The majority of Ghana's gold is hosted in the Paleoproterozoic rocks of the Birimian Supergroup and the overlying Tarkwaian Group, which generally occur collectively in deformed, southwest to northeast trending belts that have been intruded by granites (Fig. 1). These belts, generally referred to as the Birimian belts or Ghana's principal gold belts, are from southeast to northwest, the: Kibi-Winneba Belt; Ashanti Belt; Manso Nkwanta/Asankrangwa Belt; Sefwi Belt; Bui Belt; Bole-Navrongo Belt (Fig. 1); Wa-Lawra Belt (Griffis et al., 2002); and Julie Belt to the north of the area shown in Fig. 1 (Amponsah et al., 2015b). The two main types of mineralisation occurring in these belts are mesothermal quartz-vein associated gold and palaeoplacer gold (e.g. Eisenlohr, 1992; Oberthür et al., 1995; Griffis et al., 2002; Pigois et al., 2003).

This contribution aims to review and summarise the main aspects related to gold in Ghana as available in literature, namely: the history of gold exploration, mining and production; the occurrence and general geological features of the main gold deposit types; the timing and genesis of the main gold deposit types; the exploration potential for gold; and the future potential for gold mining in Ghana. The general geological setting of Ghana will also be summarised. The majority of the focus will be on the geological aspects of the gold deposits.

\section{History of gold exploration, mining and production in \\ Ghana}

The history of gold mining in Ghana is intricately linked to the general regional development of West Africa which has more than 2,000 years of recorded history. This history can essentially be divided into three periods: early regional development from $300 \mathrm{BC}$ to $1500 \mathrm{AD}$; European trade from $1500 \mathrm{AD}$ to the mid-nineteenth century; and the modern mining period from the mid-nineteenth century to the present day. These periods are briefly summarised below. More complete reviews on the history of gold mining, trade and production in Ghana can be found in Griffis et al. (2002) and Hilson (2002). It is important to note that in older literature, present day Ghana was referred to as the Gold Coast (e.g. Ellis, 1893; Junner, 1940; Ward, 1967), the name given to the British and other European colonies established in the region in the $1800 \mathrm{~s}$, and was renamed Ghana when the country won independence in 1957.

\section{Early regional development}

Although it is hard to establish the earliest record of gold mining in the West Africa region and more specifically Ghana, it is likely

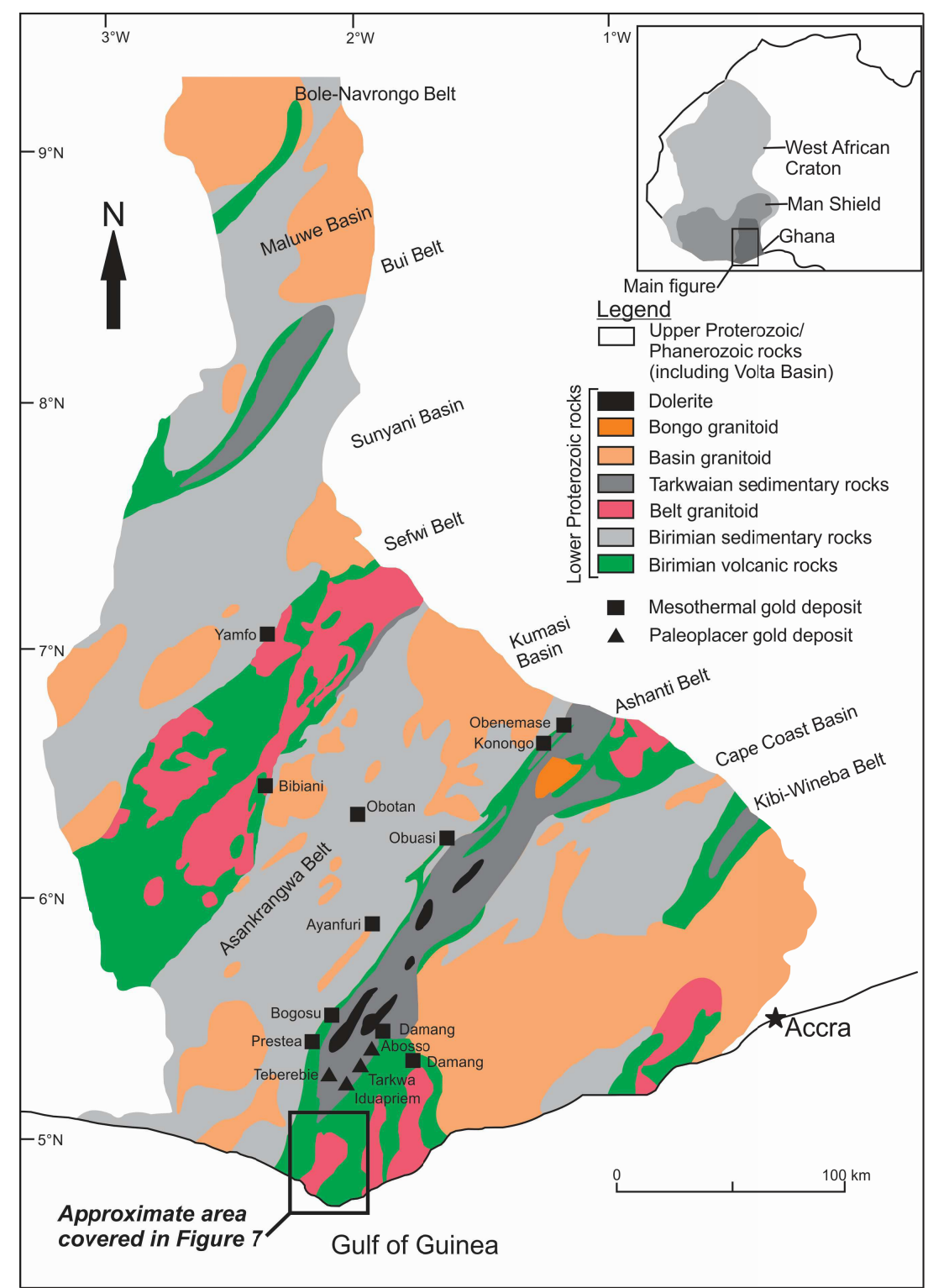

Figure 1: Simplified geological map of southwestern Ghana showing the gold-bearing belts as well as the location of the most well-known mesothermal and palaeoplacer gold deposits (adapted from Pigois et al., 2003). 
that by between $500 \mathrm{BC}$ and $300 \mathrm{AD}$ there was sustained gold production in the region. This is indicated by: possible trade with Carthaginian, Phoenician and Greek expeditions between approximately 500 and 100 BC (Ellis, 1893; Ward, 1967); reestablished northern trade routes between West Africa and the Arab world by $500 \mathrm{BC}$ and the minting of gold coins by the Roman Empire on the coast of modern day Tunisia by $300 \mathrm{AD}$ (Illife, 1995; Griffis $e t$ al., 2002).

Trade expanded in the West African region from the third century onwards due to the introduction of camels from Asia, and from this time many accounts of gold-rich kingdoms across the region were recorded, which included the Ancient Kingdom of Ghana (Griffis et al., 2002; Hilson, 2002). The latter was at the peak of its influence by $1000 \mathrm{AD}$, through control of the upper reaches of the Niger and Senegal Rivers and its control over the Bambouk goldfields, which are situated in the area known today as the Kedougou-Kenieba Inlier, the site of the present day Sadiola goldfields in Mali. The Mali Empire became the most influential force in the region in the late $11^{\text {th }}$ century $\mathrm{AD}$ after the Ancient Kingdom of Ghana was conquered by its Berber Muslim neighbours. The Mali Empire was followed by the Songhay Empire, centered in the city of Gao, until the latter was overthrown in the late 1500s by forces from Morocco (Griffis et al., 2002). The main external influence in West Africa would remain the Islamic world (Hilson, 2002), until the arrival of Portuguese merchants in the late fifteenth century (Griffis et al., 2002).

Although little is known about the precise mining techniques employed in ancient Ghana, the majority of gold is thought to have been recovered by collecting and panning material in alluvial settings (Hilson, 2002). Shallow pit and deeper shaft mining are also thought to have been practiced to lesser extents. Gold production in West Africa has been estimated to have been 2,000 to 5,000 ounces per year from 0 to $500 \mathrm{AD}, 5,000$ to 10,000 ounces per year from 500 to $1000 \mathrm{AD}$ and 15,000 to 25,000 ounces per year from 1000 to 1500 AD (Griffis et al., 2002).

\section{European trade}

Due to general shortages of gold on the European continent during the fifteenth century, European interest in gold in West African gold grew rapidly (Hilson, 2002). The first formal European visit to present day Ghana was made by a Portuguese envoy in 1471, which was shortly followed by the erection of the Sao George castle along the coast, as well as other castles, during the early sixteenth century. The main Portuguese focus during their occupation of West Africa was gold trade with local tribes and independent African states (Griffis et al., 2002), although two gold deposits were mined by the Portuguese themselves during the early seventeenth century (Hilson, 2002). Gold production during the Portuguese occupation of West Africa between 1493 and 1600 , is estimated to have been approximately 8.2 million ounces (Addy, 1998).

Although their trading in West Africa commenced in 1595, the Dutch became more aggressive in their trading policies in West Africa during the early seventeenth century, leading to the establishment of several trading forts as well as the removal of the Portuguese from some of their castles. During this time the slave trade became the dominant European interest in West Africa, and although the gold trade was still significant, gold production in Ghana declined from 1600 to 1900 . Dutch dominance was short-lived due to renewed trade and competition from England in 1632, which led to a 150 year power struggle in West Africa between these two nations. Other European nations that had trade interests and settlements in the region were France, Denmark and Prussia. From 1601 to 1900, Ghana's gold production is estimated to have been approximately 14.4 million ounces (Ellis, 1893; Addy, 1998; Griffis et al., 2002; Hilson, 2002).

The period of strong European gold trade in West Africa was also marked by the rise of the Ashanti Nation in Ghana in the mid-1600s, through the collaboration of numerous clans close to present day Kumasi. Mining of gold within their region led to great wealth and control of a region larger than present day Ghana by the end of the eighteenth century. The Ashantis were also involved in bedrock mining of gold-rich quartz veins by the early nineteenth century (Griffis et al., 2002). Friction between the Ashanti Nation and Great Britain grew in the nineteenth century due to the latter's control over trade and their desire to reduce slavery in West Africa, which culminated in hostilities. The British defeated the Ashantis in Kumasi in 1874, leading to the Gold Coast formally being declared a British colony (Ellis, 1893; Griffis et al., 2002).

\section{Modern mining}

The declaration of the Gold Coast as a British Colony in 1874 led to a more direct interest in exploration and mining, through new technologies, of Ghana's gold deposits by foreign companies (Griffis et al., 2002). French entrepreneur Marie-Joseph Bonnat learned of gold workings in Tarkwa (Fig. 1), during the time he was held captive by the Ashantis (Hilson, 2002) from 1871 to 1874 . This led him to lease a small mining concession near Tarkwa from the Wassa chief in 1878, followed by the first mining activities at Tarkwa by the African Gold Coast Company (Fig. 2) (Griffis et al., 2002). There were also mass gold rushes in the region (Hilson, 2002). Although the discovery of gold in the Witwatersrand in South Africa in 1886 renewed interest in Africa's gold potential, it had no immediate effect on production in Ghana. Only with the start of the Anglo-Boer War was there an outflow of capital from South Africa, followed by re-investment in Ghana. The majority of the mining and prospecting during the late nineteenth century was concentrated at Tarkwa (Fig. 2) and Prestea (Griffis et al., 2002; Hilson, 2002) (Fig. 1). The mines exploited by European companies in the late nineteenth century were located by local inhabitants who, after sampling soils and determining the gold contents, guided foreigners to the sites (Hilson, 2002).

The late nineteenth century also marked the first large scale gold mining at Obuasi (Fig. 1), from 1895 onwards (Griffis et al., 2002), which led to a significant increase in gold production in Ghana (Ward, 1967; Hilson, 2002). These deposits had previously been exploited by the Denkyera and the Ashantis (Ward, 1967; Hilson, 2002). Ashanti Goldfields Corporation Limited was listed in 1897 by Cade and his Gold Coast partners and by 1902 the company was producing 20,000 ounces of gold per year (Griffis et al., 2002).

Gold production during early European involvement in Ghana was the lowest recorded up to that point with 360,000 ounces produced between 1880 and 1900. However, from 1902 onwards, mining in the region grew so that by 1914 the annual production of gold from Ghana was approximately 410,500 ounces, the majority coming from underground mines in Tarkwa, Obuasi and Prestea (Fig. 1). Due to Britain dropping the gold standard following the First World War, gold production in Ghana decreased and stagnated from 1918 to 1929 ( $\sim 200,000$ ounces per year average). This, in turn, was followed by a mining boom in the 1930 s caused by the stock market crash of 


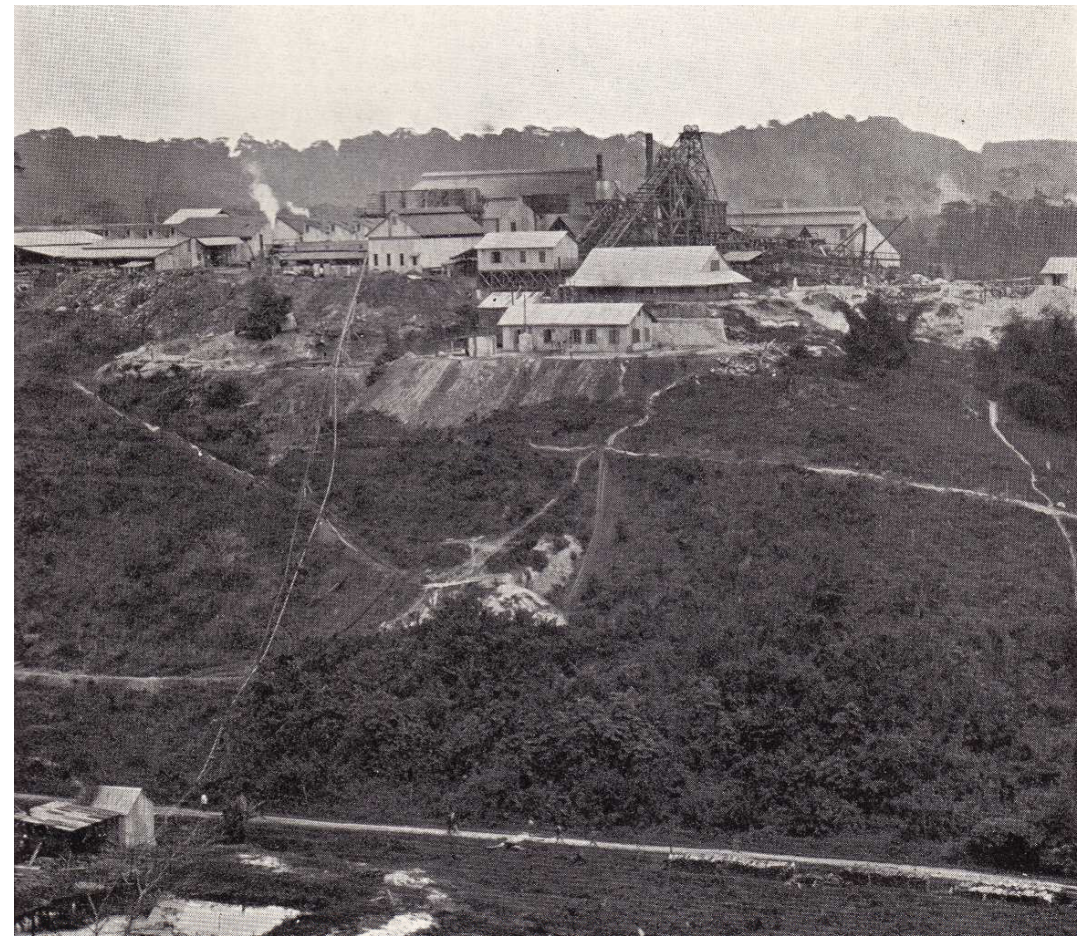

Figure 2: A picture of Tarkwa Mine taken in the early 1900s (Stokes, 1908).

advantages (Addy, 1998; Griffis et al., 2002; Hilson, 2002; Tsikata, 1997). Between 1983 and 1998 an estimated US $\$ 4$ billion was invested in Ghana's mining sector, the majority of that spent on gold exploration and mining (Aryee, 2001; Hilson, 2002). By 2002 some 237 companies were exploring for gold and an additional 18 companies had operating gold mines in Ghana (Hilson, 2002). New gold exploration and mining concessions over this period included Konongo, Bogosu, Bonte River, Abosso, Obotan and Yamfo (Griffis et al., 2002). From the low point in 1982, gold production in Ghana rapidly grew to somewhere between 975,000 and 998,000 ounces in 1992, and between $1,707,460$ and 1,758,000 ounces in 1997 (Tsikata, 1997; Aryee, 2001; Griffis et al., 2002; Hilson, 2002), peaking at between 2,590,000 and 2,852,000 ounces in 1999 (Griffis et al., 2002; Hilson, 2002).

\section{Gold production since 2000}

By 2001 Ghana's gold production had declined to $2,369,906$ ounces (Griffis et al., 2002) and was approximately 2,227,000 ounces in 2004 (BermúdezLugo, 2004). The decline in production during this period was due to a variety of factors including: fallout from

1929 and investors returning to gold for financial refuge (Griffis et al., 2002). By 1933-1934, annual production in Ghana had climbed to 336,065 ounces (Hilson, 2002) and, by the end of the 1930s, it was 819,000 ounces (Griffis et al., 2002). This mining and exploration boom also led to great advances in the documentation of the geology and gold deposits of the then Gold Coast (e.g. Junner, 1935 ; 1940).

The Second World War (1939-1945) had a highly detrimental effect on gold mining in Ghana due to declining availability of sea tankers, fuel and skilled workforce shortages, which resulted in decreasing annual production to 541,000 ounces by 1945 . Following the war gold production fluctuated due to political unrest related to local workforce unhappiness and widespread calls for Ghana's independence from Great Britain. The latter was achieved in 1957. Following Ghana's independence, the gold mining sector reached peak production of approximately one million ounces per annum by the early 1960s. However, State intervention in the mining sector and nationalisation of the majority of the gold mines led to a steady decline in gold production over the next two decades, reaching a 50 -year low point of 232,000 ounces in 1982 . This coincided with a general decline in Ghana's economy during the 1960s and 1970s. The Quashie report, submitted to the Ghana government in 1980, highlighted the poor status of Ghana's gold sector and made recommendations on how to overhaul the mining sector. This was also followed by Ghana's Economic Recovery Plan (ERP) in 1983, with assistance from the International Monetary Fund (IMF), World Bank and other creditors (Addy, 1998; Griffis et al., 2002; Hilson, 2002; Tsikata, 1997).

Ghana's mineral sector underwent significant recovery and growth from 1986 onwards following the ERP reforms in the Country's mineral policies and the establishment of the Minerals Commission. These changes, which included the implementation of the Minerals and Mining Law, made investment for foreign mining companies more attractive through tax breaks as well as royalties and mineral rights the BRE-X scandal that reduced capital investment in gold mining and exploration worldwide; a lower gold price; new prospects that underperformed when they went into production; and multiple geotechnical issues at established operations (Griffis et al., 2002; Bermúdez-Lugo, 2004). This was followed by a steady increase in production to approximately 2,547,000 ounces in 2007 and 2,927,000 ounces in 2011, mainly due to upgrades and increased production throughputs and recoveries at established operations (Bermúdez-Lugo, 2011). The increase continued, with annual production estimates for 2012 and 2013 of 3,166,483 and 3,192,648 ounces respectively (Ghana Chamber of Mines, 2013; 2014). However, gold production fell to $3,167,755$ ounces in 2014 due to a drop in production from some major producers caused by higher-than-average rainfall and other mining and processing challenges (Ghana Chamber of Mines, 2014). At the time of writing, the main gold producing prospects, in order of decreasing production during 2014, were: Gold Fields Ghana Tarkwa; Newmont Akyem; Newmont Ahafo; Kinross Chirano; Precious Minerals Marketing Company (PMMC) Gold, which sources gold from small-scale and artisanal mining; AngloGold Ashanti Obuasi; Perseus Mining Ashanti Belt Projects; Gold Fields Damang; AngloGold Ashanti Iduapriem; Golden Star Bogoso Prestea; Golden Star Wassa; and Adamus Resources (Ghana Chamber of Mines, 2014).

\section{Regional geological setting of Ghana}

The majority of Ghana is underlain by metamorphosed Palaeoproterozoic (2300-1900 Ma) rocks of the volcano-sedimentary Birimian Supergroup and the overlying clastic sedimentary Tarkwaian Group (Oberthür et al., 1998; Griffis et al., 2002) that make up the Man Shield (also known as the Leo Shield) of the West African Craton in Ghana (Griffis et al., 2002) (Fig. 1). These units host the majority of the gold deposits in Ghana and are the focus of this section. However, numerous Palaeoproterozoic granitoids, which may host gold mineralisation (Oberthür et al., 1995; Yao and Robb, 2000; Yao 
et al., 2001), mafic intrusions as well as younger geological successions and intrusions, also occur and are briefly discussed. It is important to note that all the Birimian and Tarkwaian units in Ghana have been metamorphosed to lower greenschist facies, with local variations in the grade of metamorphism, especially around granitic intrusions, as well as in higher grade areas in parts of the northern belts (Griffis et al., 2002). However, the preserved greenschist facies metamorphism could be a retrograde assemblage that was preceded by peak amphibolite facies metamorphism (John et al., 1999; Yao and Robb, 2000). In addition, the Palaeoproterozoic granitoids have also been metamorphically overprinted with features such as foliation and mylonitisation (John et al., 1999). The metamorphism of the Palaeoproterozoic units is discussed and reviewed by John et al. (1999) and Griffis et al. (2002) and will not be discussed in detail here.

\section{West African Craton and the Man Shield}

The West African Craton is Archean to Palaeoproterozoic in age and stretches from the Little Atlas mountains of Morocco in the north, to the Gulf of Guinea in the south. It is bound by younger mobile belts to the west and east, close to the northwestern coast of Africa, and along the northward extension of the border between Benin and Nigeria, respectively. It comprises three metamorphic and magmatic shields separated by two supracratonic sedimentary basins. The shields include: the Archean to Palaeoproterozoic Man Shield in the south; the Archean to Palaeoproterozoic Reguibat Shield in the north; and the Palaeoproterozoic Anti-Atlas Belt in the extreme north. The Taoudeni Basin occurs in the center and the Tindouf Basin in the north of the West African Craton (Ennih and Liégeois, 2008).

The Man Shield consists of an Archean nucleus to the west and Palaeoproterozoic Birimian units in the central and eastern parts (Griffis et al., 2002; Ennih and Liégeois, 2008). The latter units comprise metasediments, metavolcanics and associated intrusive complexes that cover much of Ghana, Côte d'Ivoire, Burkina Faso, southern Mali, northern Guinea and the southwest corner of Niger (Griffis et al., 2002).

\section{Birimian Supergroup}

The Birimian Supergroup was originally subdivided into the Lower Birimian comprising volcano-sedimentary units and the Upper Birimian comprising metavolcanics (Junner, 1935; 1940; Oberthür et al., 1997; Griffis et al., 2002). A more recent stratigraphic subdivision of the Birimian Supergroup proposed by Adadey et al. (2009) divides it into: the Sefwi Group composed of mica schists and metavolcanics; and the Kumasi Group composed of metasediments and intercalated andesitic beds (Perrouty et al., 2012).

The volcanic belts (also termed greenstone belts) of the Birimian Supergroup strike in an approximately northeasterly direction for hundreds of kilometers through Ghana (Fig. 1), whilst the southern belts are thought to extend into southeastern Burkina Faso and southwestern Niger. The belts have widths of approximately 20 to $70 \mathrm{~km}$, narrowing to 10 to $20 \mathrm{~km}$ in the north of Ghana (Griffis et al., 2002). The belt units are dominantly tholeiitic lavas, but also contain ultramafic rocks and intercalations of dacitic and rhyodacitic lavas and pyroclastics of andesitic-dacitic and calc-alkaline character (Attoh et al., 2006; Dampare et al., 2008; Berge, 2011). As mentioned previously, Birimian Supergroup volcanic belts, from southeast to northwest of Ghana, include the: Kibi-Winneba Belt; Ashanti Belt;
Manso Nkwanta/Asankrangwa Belt; Sefwi Belt; Bui Belt; BoleNavrongo Belt; Wa-Lawra Belt; and Julie Belt (Fig. 1).

The sedimentary units on the margins of the volcanic belts and in the broad intervening basins (Fig. 1) are metamorphosed and tightly folded (Fig. 3). The basins are approximately 60 to $70 \mathrm{~km}$ wide in southern Ghana and narrow to the north (Griffis et al., 2002). Various lithofacies with their respective depositional environments have been identified marginal to the belts and in the basins: wacke, turbiditerelated facies (lower slopes of volcanic ridges); volcaniclastic/argillite facies (proximal to volcanic ridges); argillite/volcaniclastic facies (distal to volcanic ridges); argillite facies (low energy environments in central parts of basins); and chemical sediment facies (transitional zones between volcanic belts and basins; Hirdes et al., 1993; Griffis et al., 2002). The Birimian Supergroup metasedimentary basins in Ghana include: the Cape Coast Basin in south-central Ghana; the Kumasi and Sunyani Basins in southwestern Ghana; and the Maluwe Basin in western Ghana (Fig. 1).

The formation of the Birimian volcanic belts has been interpreted to have occurred in an oceanic island arc setting (Sylvester and Attoh, 1992; Dampare et al., 2008). However, Feybesse et al. (2006) implied a more complex model where plutonic activity and deposition on a continental margin, followed by juvenile basic intrusive and extrusive magmatism, and finally old continental and juvenile crust collision, formed the tectonic setting in which the volcanic belts formed. The Birimian Supergroup metasediments are generally considered to have been derived from the adjacent volcanic belts and deposited along the volcanic ridges and in adjacent basins (Griffis et al., 2002).

Age constraints from zircons in the metavolcanics of the Birimian Supergroup vary between $2162 \pm 6 \mathrm{Ma}$ and $2266 \pm 2 \mathrm{Ma}$, whereas detrital zircon grains from the metasediments yield ages of between 2180 and $2130 \mathrm{Ma}$ (Davis et al., 1994; Oberthür et al., 1998; Griffis et al., 2002; Adadey et al., 2009; Loh et al., 2009; Perrouty et al., 2012).

\section{Tarkwaian Group}

The Tarkwaian Group and its equivalents consist of a variety of sandstones, conglomerates and argillites that are found within many of the volcanic belts in West Africa. In Ghana, the Tarkwaian Group is best developed within the Ashanti Belt (Fig. 1), where it attains a thickness of approximately 2,500 m, and the Bui Belt, where it attains a thickness of approximately $9,000 \mathrm{~m}$. Occurrences of the Tarkwaian Group have also been found on the eastern margin of the Sefwi Belt, in the Kibi-Winneba belt and the northern Nangodi Belt (Griffis et al., 2002).

The Tarkwaian Group in the Ashanti Belt formed in a long, narrow basin with the western fault-bounded contact forming a half-graben. It is subdivided into four major units, which are, from the base to the top: the Kawere Group; the Banket Series (also referred to as Banket Formation); the Tarkwa Phyllite; and the Huni Sandstone. The Kawere Group comprises conglomerates and sandstones and varies in thickness between 250 and $700 \mathrm{~m}$. The overlying Banket Series (Fig. 4) comprises conglomerates, made up of Birimian quartz pebbles and volcanic clasts, with interbedded cross-bedded sandstones. The Banket Series hosts the Tarkwa Placer gold deposit $(<100 \mathrm{~m}$ thick gold zone), attains an estimated maximum thickness of $600 \mathrm{~m}$ and grades upwards into the Tarkwa Phyllite, which is up to $400 \mathrm{~m}$ thick. The latter grades into the uppermost Huni Sandstone that comprises an approximately $1,400 \mathrm{~m}$ thick sequence of sandstones with 


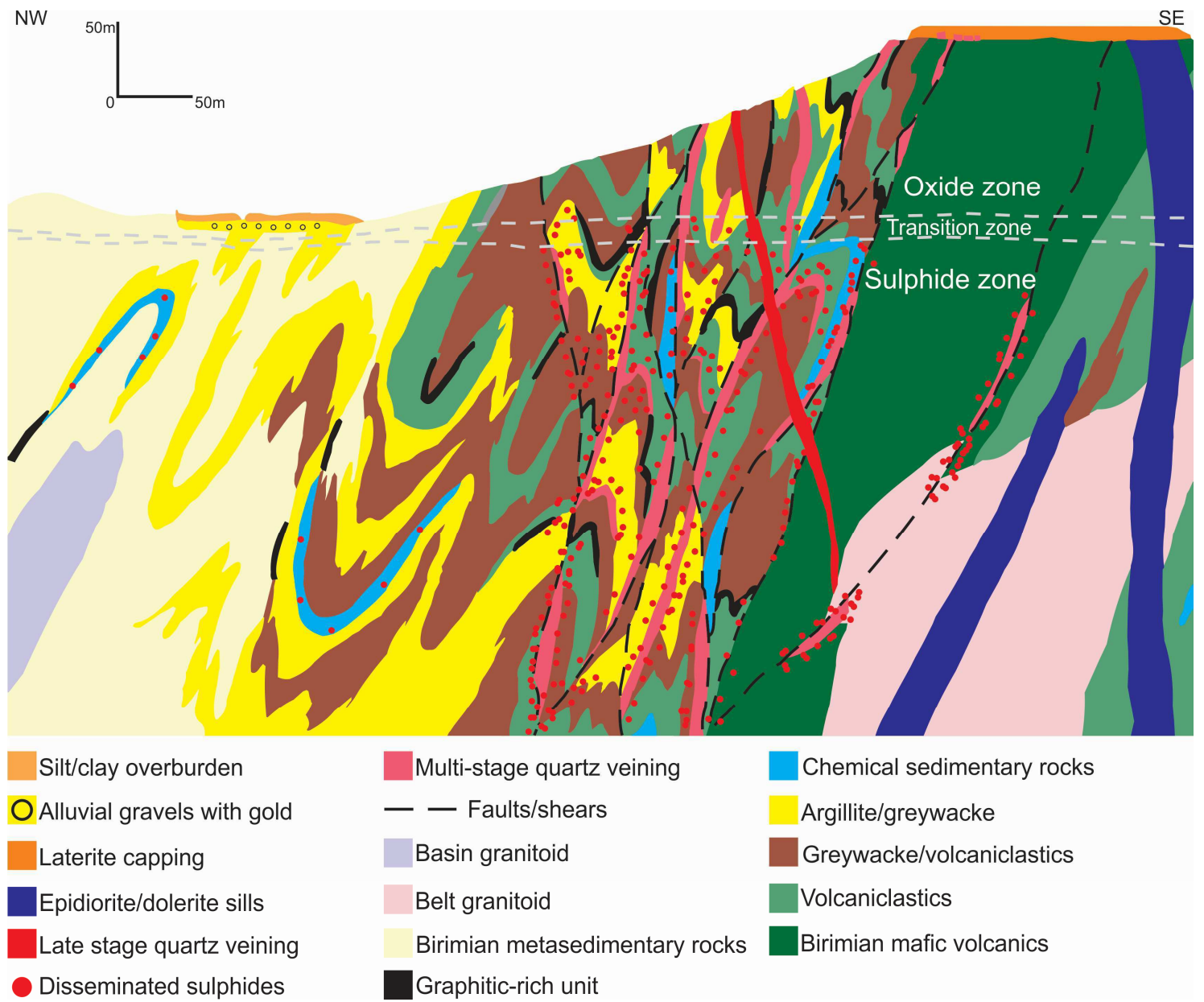

Figure 3: Northwest to southeast schematic cross section of a typical Ashanti-type, Birimian mesothermal quartz vein and quartz, veinassociated sulphide gold deposit (adapted from Griffis et al., 2002).

interbedded quartzites and phyllites, intruded by minor dolerite sills (Kesse, 1985; Strogen, 1991; Griffis et al., 2002; Pigois et al., 2003; Perrouty et al., 2012).

In the Bui Belt (Fig. 1), the Tarkwaian Group consists of two sedimentary cycles within an elongate, overturned syncline in the center of the belt (Kiessling, 1997; Griffis et al., 2002): the Bui cycle ( 2,000 $\mathrm{m}$ thick) comprising the Nuapo, Kane and Mundale Formations; and the Sabiyi cycle ( 7,000 m thick), comprising the Nyanchulo and Tombe Formations. The Bui cycle only occurs in the northern part of the basin, whereas the Sabiyi cycle occurs across the entire basin. Both cycles have quartzite at the base, coarsening upwards to conglomerates which are, in turn, overlain by upward fining quartzites. The predominantly siltstone Mundale Formation occurs at the top of the Bui cycle. The Tarkwaian conglomerates of the Bui Belt contain substantial concentrations of Palaeoplacer gold as mined in Tarkwa (Griffis et al., 2002).

The depositional setting of the Tarkwaian Group units is very different to that of the underlying Birimian Supergroup sedimentary units. The conglomeratic units of the Tarkwaian Group are interpreted as having been deposited in alluvial fans and then reworked by braided stream channels (Sestini, 1973; Kiessling, 1997; Griffis et al., 2002). The latter are thought to have concentrated fine particles of gold within the channel conglomerates.

The maximum age of deposition for the Tarkwaian Group is constrained to approximately 2133 to 2132 Ma based on detritial zircons from the Kawere Group and Banket Series (Davis et al., 1994; Hirdes and Nunoo, 1994; Pigois et al., 2003; Perrouty et al., 2012), although Perrouty et al. (2012) estimate, from all available concordant zircon data, that deposition could have started as late as $2107 \mathrm{Ma}$. From the intrusion of metagabbro sills (Adadey et al., 2009) and granitoids (Oberthür et al., 1998) respectively, the age of deposition for the Tarkwaian Group is also constrained to approximately 2102 to $2097 \mathrm{Ma}$ (Perrouty et al., 2012).

\section{Palaeoproterozoic intrusions}

Granitoid intrusions of Palaeoproterozoic age are common in Ghana, with two types distinguished: belt granitoids (traditionally called Dixcove-type); and basin granitoids (traditionally called Cape Coast-type; Yao et al., 2001; Griffis et al., 2002) (Fig. 1). The belt granitoids are small to medium in size, older than the basin granitoids (2145-2190 Ma), similar to I-type granitoids and generally associated with volcanic belts. The basin granitoids, in contrast, occur in large batholithic complexes, are younger than the belt granitoids (2090$2125 \mathrm{Ma}$ ), similar to S-type granitoids and generally intrude into sedimentary basins (Griffis et al., 2002). These two types of granitoids also have further distinguishing characteristics with regards to mineralogy, geochemistry, contact metamorphism, alteration and textures, which are reviewed in more detail by Yao and Robb (1998) and Griffis et al. (2002). An economic classification also exists where 


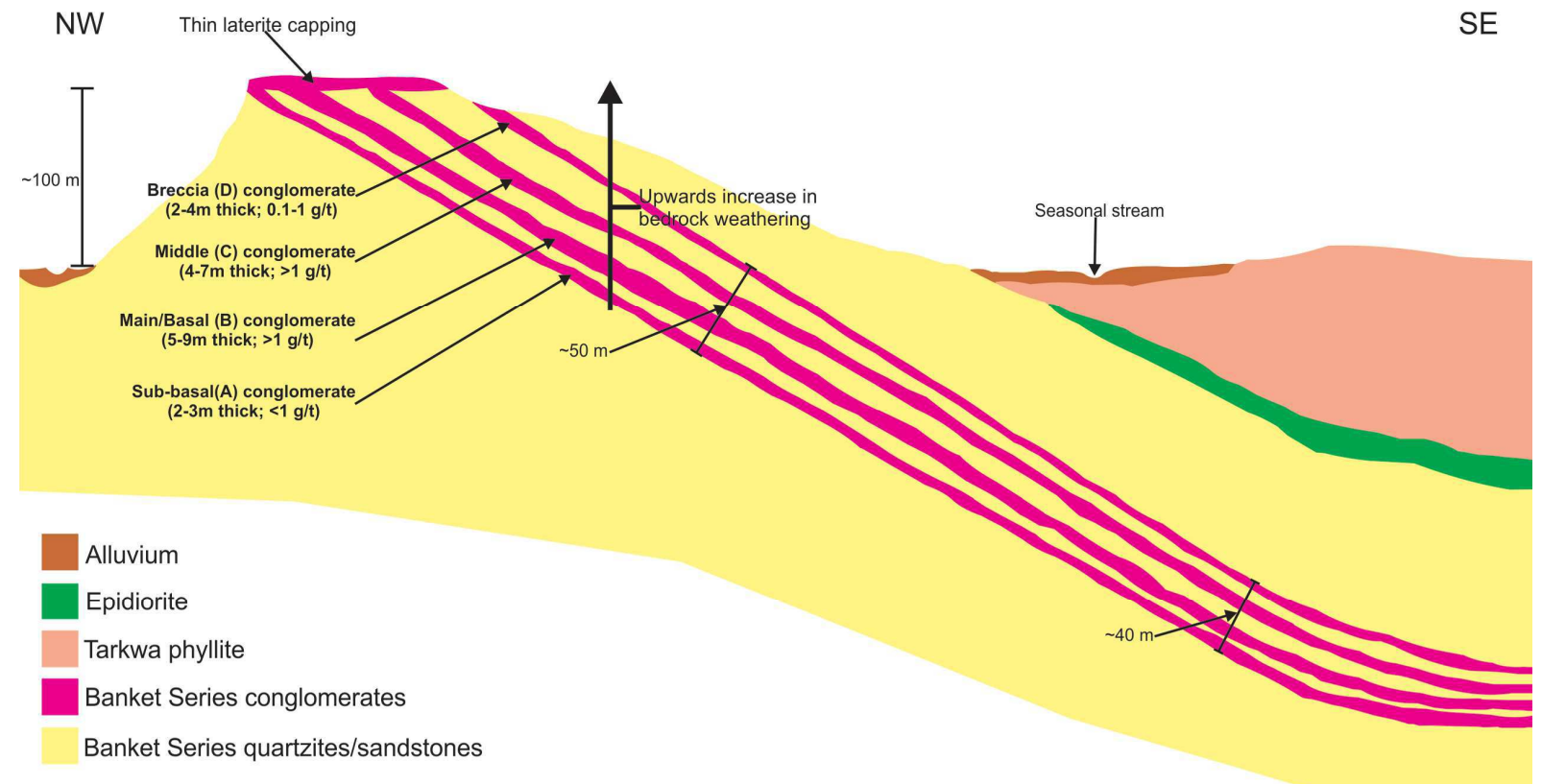

Figure 4: Northwest to southeast cross section of a typical Banket Formation-hosted Tarkwaian palaeoplacer gold deposit (adapted from Griffis et al., 2002).

the granitoids are classified as mineralised and unmineralised (Yao and Robb, 1998; Yao et al., 2001). The Palaeoproterozoic belt and basin granitoids have generally intruded both the Birimian volcanic belts and sedimentary basins across northern, western and southern Ghana (Yao and Robb, 2000).

Mafic intrusives, likely of Palaeoproterozoic age, also occur in the majority of volcanic belts of Ghana and are abundant in the Ashanti and Sefwi Belts (Griffis et al., 2002). They generally appear to postdate belt granitoids but pre-date the metamorphism of the volcanic belts. It is thought that two compositional types are most common: sills and feeder dykes with tholeiitic basalt affinity in areas dominated by mafic flows; and later stage gabbro-dioritic intrusions. In the Ashanti belt they occur as extensive sills and minor dykes intruding the Tarkwaian clastic sediments, with airborne geophysical data suggesting similar mafic intrusions in the Birimian volcanics and volcaniclastics (Griffis, 1998; Griffis et al., 2002). Another example of a larger complex hosting mafic intrusives is the Mpohor Intrusive Complex, located approximately $15 \mathrm{~km}$ northwest of Takoradi in southwestern Ghana, which hosts the Mpohor gold deposit. The Mpohor intrusions have granodioritic, dioritic and gabbroic compositions, mark the end of the Eoeburnean magmatic phase (Perrouty et al., 2012; 2014) and have a possible link with the previously mentioned Ashanti Belt mafic sills (Griffis, 1998; Griffis et al., 2002).

\section{Geological units of younger age}

The sedimentary rocks of the Volta Basin cover close to one half of Ghana's surface (Griffis et al., 2002) and straddle the borders of Ghana, Togo, Benin, Burkina Faso and Niger (Porter et al., 2004). The units have a gentle dip and were deposited on the Eburnean basement of the Man Shield (Nédélec et al., 2007), marking a major Precambrian unconformity (Griffis et al., 2002). The units, from the base upwards, are indicative of a cratonic, epicontinental basin (Bombouaka Supergroup; 1,000 m thick) changing to a passive margin (Oti or Penjari Supergroup; $\sim 2,500 \mathrm{~m}$ thick) and then a foreland basin (Tamale Supergroup and overlying sandstones; $\sim 500 \mathrm{~m}$ thick), which was formed during the Pan-African orogeny (Affaton et al., 1991; Griffis et al., 2002; Porter et al., 2004). Ages for the sedimentary rocks of the Volta Basin include: approximately 993 Ma for clays from the lower Bombouaka Supergroup; approximately $660 \mathrm{Ma}$ for clays (Griffis et al., 2002) and a minimum age of 620 Ma for the Oti Supergroup (Nédélec et al., 2007); and ranges of 500 to $360 \mathrm{Ma}$ for the Tamale Supergroup (Affaton et al., 1991; Griffis et al., 2002).

In the southeastern corner of Ghana a series of northeast-trending units occur that are in fault contact with the Birimian Supergroup, Volta Basin and Eburnean granitoid units. The westernmost extension of the Togo Belt, known in Ghana as the narrow, elongate Buem Formation on the western margin, the adjacent Togo Series to the east, and the high grade Dahomeyan metamorphics on the eastern margin, occur in the southeastern corner of Ghana, along its border with Togo (Griffis et al., 2002). The Togo Belt is a collisional belt related to the Pan-African orogeny and formed during the formation of Gondwana when West Africa was accreted onto the supercontinent at approximately $610 \mathrm{Ma}$ (Hoffman, 1999; Griffis et al., 2002).

Phanerozoic sediments also occur along the coast of Ghana and in numerous offshore basins. These are described in more detail by Kesse (1985), Wright et al. (1985), Petters (1991) and Griffis et al. (2002). Mesozoic dykes are common in southern Ghana and have been shown by airborne geophysical data to extend to the north (Griffis and Agezo, 2000; Griffis et al., 2002).

\section{Deformational history of the Birimian belts}

Deformational structures, especially with regards to the mesothermal gold mineralisation, appear to be the dominant factor in controlling the distribution of gold mineralisation in Ghana's Birimian belts (Griffis et al., 2002). The Birimian Supergroup and Tarkwaian Group, which host the majority of Ghana's gold resources, have 
undergone multiple deformational events that can be linked to the Eburnean orogeny ( 2130-1980 Ma; Feybesse et al., 2006; Perrouty et al., 2012). This is especially evident in the Ashanti region in southwestern Ghana where six deformational events (termed D1 to D6) have been identified. The deformational events are as follows (Perrouty et al., 2012; 2015):

- The D1 event occurred before deposition of the Tarkwaian Group and is termed the Eoeburnean deformation event, which caused regional scale folding in the Sefwi Group metavolcanics through north-south compression. D1 synorogenic granitoids were also intruded between 2187 and $2158 \mathrm{Ma}$.

- The D2 event was an extensional phase that opened the Kumasi and Akyem basins into which the Kumasi Group was deposited. On the western side of the Ashanti Belt, the contact between the Sefwi and Kumasi Groups is marked by the Ashanti Fault.

- The D3, or Eburnean event, is characterised by large folds, formed through northwest-southeast compression within both the Birimian and Tarkwaian units.

- The D4 event is marked by small scale shear zones cross cutting D3 folds on the western Ashanti Belt. It also caused reactivation of splays of the Ashanti Fault. At Wassa gold mine a fold that is interpreted to be associated with the D4 event is observed. Both the D3 and D4 events are thought to have been contemporaneous with the Eburnean magmatic phase.

- The D5 event is characterised by small scale ( $1 \mathrm{~cm}$ to $5 \mathrm{~m}$ ) symmetrical recumbent folds that are open to tight and defined by a subhorizontal crenulation cleavage.

- The D6 event formed open folds defined by a subvertical crenulation cleavage.

Although these deformational events are defined for the Ashanti Belt, other gold-bearing belts in Ghana show similar deformational events. For example, three deformational events (defined here as $\mathrm{D}_{\mathrm{w1}_{1}}{ }^{-}$ $\mathrm{D}_{\mathrm{W} 3}$ ) have been identified in the Wa-Lawra Belt in northerwestern Ghana (Block et al., 2015; Amponsah et al., 2015a): the $\mathrm{D}_{\mathrm{w} 1}$ event, which was caused by north-south crustal compression; the $\mathrm{D}_{\mathrm{w}_{2}}$ event, which is characterised by north-south extension and exhumation of high grade terranes; and the $\mathrm{D}_{\mathrm{w} 3}$ event, which is characterised by steeply dipping northeast-, north- and northwest-trending shear zones. The Julie deposit, located in the Julie Belt in northwestern Ghana, also shows three deformational events $\left(\mathrm{D}_{\mathrm{J} 1}-\mathrm{D}_{\mathrm{J} 3}\right)$, where $\mathrm{D}_{\mathrm{J} 1}$ and $\mathrm{D}_{\mathrm{J} 2}$ correspond to the $\mathrm{D}_{\mathrm{w} 1}$ and $\mathrm{D}_{\mathrm{W} 3}$ events in the Wa-Lawra Belt respectively (Amponsah et al., 2015b). The $\mathrm{D}_{\mathrm{J} 3}$ event is characterised by northeast- to southwest-orientated brittle faulting (Amponsah $e t$ al., 2015b).

The $\mathrm{D}_{\mathrm{W} 1}$ and $\mathrm{D}_{\mathrm{W} 2}$ events in the Wa-Lawra Belt and $\mathrm{D}_{\mathrm{J} 1}$ event in the Julie Belt likely correspond to the D1 and D2 events in the Ashanti Belt. The $\mathrm{D}_{\mathrm{W} 3}$ event in the Wa-Lawra and the $\mathrm{D}_{\mathrm{J} 2}$ event in the Julie Belts show similarities to the D3 and D4 events of the Ashanti Belt. The $\mathrm{D}_{\mathrm{J} 3}$ event could also possibly correspond to the $\mathrm{D} 4$ event of the Ashanti Belt. It therefore appears that at least the D1 to D4 events defined for the Ashanti Belt are representative of the gold-bearing Birimian belts of southwestern, western and northwestern Ghana.

\section{Geological setting and description of main gold mineralisation types in Ghana}

Studies of gold occurrences in West Africa have identified five regional types of gold deposits (Griffis et al., 2002). These are: tourmalinised turbidite-hosted deposits; disseminated gold-sulphide deposits; Tarkwaian palaeoplacers; mesothermal auriferous arsenopyrite and quartz vein mineralisation (from here on referred to as mesothermal quartz vein and quartz vein-associated sulphide type mineralisation); and mesothermal gold-quartz vein deposits. The mesothermal quartz vein and quartz vein-associated sulphide type mineralisation hosted in Birimian Supergroup units (Figs. 1 and 2) and the Tarkwaian palaeoplacer type hosted in Tarkwaian Group units (Figs. 1 and 3), are the most significant types of gold occurrences in Ghana. In the Ashanti Belt, Oberthür et al. (1995) have further subdivided the mesothermal quartz vein and quartz vein-associated sulphide type mineralisation into shear-zone hosted quartz vein types and quartz vein associated sulphide ore types. This subdivision is commonplace (e.g. Leube et al., 1990; Oberthür et al., 1998; Allibone et al., 2002b; Kuma et al., 2010; Fougerouse et al., 2015). Oberthür et al. (1995) also added disseminations and stockwork hydrothermal gold mineralisation in basement-type granitoids as an additional mineralisation type. Therefore deposits belonging to the mesothermal quartz vein and quartz vein-associated sulphide, palaeoplacer and hydrothermal mineralisation in granitoid types, are the most commonly occurring in Ghana and will be the focus of this review. The other three regional type occurrences for West Africa are generally absent or insignificant in Ghana, although a genetic link has been suggested between the mesothermal quartz vein and quartz vein-associated sulphide type mineralisation and turbidite-hosted deposit types (Berge, 2011). Supergene modification of mesothermal vein gold mineralisation has also been documented in the Ashanti Region (Bowell, 1992).

Table 1 summarises the location, mineralisation types, average gold grades and resources of major gold occurrences in Ghana.

\section{Mesothermal quartz vein and quartz vein- associated sulphide type mineralisation}

Mesothermal quartz vein and quartz vein-associated sulphide type mineralisation (Fig. 3), sometimes referred to as Ashanti shear zone type mineralisation, is the most important gold mineralisation type in Ghana. Obuasi (also referred to as the Ashanti deposit), the largest gold mine in the region, is the type locality for this mineralisation type. Other deposits in Ghana (Fig. 1; Table 1) where this is an important mineralisation type include Bepkong, Bibiani, Bogosu, Damang, Konongo, Prestea, Wassa and the Yamfo district. This mineralisation type has been estimated to have a total gold inventory of approximately 1,100 t ( 32 Moz) in Ghana (Milési et al., 1991; Mumin et al., 1994; Oberthür et al., 1997; Yao et al., 2001; Griffis et al., 2002; Allibone et al., 2002b; Pigois et al., 2003; Tunks et al., 2004; Amponsah et al., 2015a Fougerouse et al., 2015; Parra-Avila et al., 2015; Perrouty et al., 2015).

Generally, mesothermal quartz vein and quartz vein-associated sulphide type mineralisation is confined to tectonic corridors of up to more than $50 \mathrm{~km}$ long and several kilometers wide (Milesi et al., 1992; Griffis et al., 2002) that trend north northeast to northeast and are concentrated along the margins of Ghana's Birimian belts (Griffis et al. 2002) (Fig. 1). Ghana's Birimian or 'greenstone' belts are made up of the metasediments and metavolcanics of the Birimian Supergroup along with younger Tarkwaian Group siliciclastics. The mineralisation appears to be strongly associated with regional structures such as shear zones and fault systems. At Obuasi, gold 
Table 1: The location, type of gold mineralisation, average grade and estimated resources of known gold deposits in Ghana. The mesothermal vein type mineralisation listed in the table is short for the mesothermal quartz vein and quartz vein-associated sulphide type or Ashanti-type mineralisation.

\begin{tabular}{|c|c|c|c|c|c|}
\hline Name of deposit & Location & Mineralisation types & $\begin{array}{l}\text { Average } \\
\text { grades }\end{array}$ & $\begin{array}{l}\text { Total resource } \\
\text { estimates (recent } \\
\text { and/or past) }\end{array}$ & References \\
\hline Atewa Range & $\begin{array}{l}\text { Kibi-Winneba Belt } \\
\text { Southeastern Ghana, near the } \\
\text { town of Kibi }\end{array}$ & Mesothermal vein type & NA & NA & Griffis et al. (2002) \\
\hline $\begin{array}{l}\text { Winneba-Mumford } \\
\text { Area }\end{array}$ & $\begin{array}{l}\text { Southern extension of } \\
\text { Kibi-Winneba Belt }\end{array}$ & $\begin{array}{l}\text { Mesothermal vein type; } \\
\text { Palaeoplacer type }\end{array}$ & $\sim 0.5-1.0 \mathrm{~g} / \mathrm{t}$ & NA & Griffis et al. (2002) \\
\hline Abosso & $\begin{array}{l}\text { Ashanti Belt/Kumasi Basin } \\
\text { Southern Ashanti Belt, } \sim 20 \mathrm{~km} \text { north- } \\
\text { east of Tarkwa, south of Damang }\end{array}$ & $\begin{array}{l}\text { Mesothermal vein type; } \\
\text { Palaeoplacer type }\end{array}$ & $\sim 7 \mathrm{~g} / \mathrm{t}$ & $\sim 0.6 \mathrm{Moz} \mathrm{Au}$ & Griffis et al. (2002) \\
\hline Anwia & $\begin{array}{l}15 \mathrm{~km} \text { northwest of Axim, } 1 \mathrm{~km} \text { north } \\
\text { of Nkroful, Kumasi Basin }\end{array}$ & Mesothermal vein type & $\sim 1.3 \mathrm{~g} / \mathrm{t}$ & $\sim 0.15 \mathrm{Moz}$ & Griffis et al. (2002) \\
\hline Ayanfuri & $\begin{array}{l}\text { Central Ashanti Belt, } 16 \mathrm{~km} \text { west of } \\
\text { Dunkwa-on-Ofin }\end{array}$ & $\begin{array}{l}\text { Mesothermal vein type; } \\
\text { Granitoid type }\end{array}$ & $\sim 1.5 \mathrm{~g} / \mathrm{t}$ & $0.2 \mathrm{Moz} \mathrm{Au}$ & Griffis et al. (2002) \\
\hline Benso & $\begin{array}{l}\text { Eastern limb of Ashanti Belt, } \sim 38 \mathrm{~km} \\
\text { southwest of Wassa deposit }\end{array}$ & Mesothermal vein type & NA & NA & Parra-Avila et al. (2015) \\
\hline Besease & $\begin{array}{l}7 \mathrm{~km} \text { west of Nkawkaw, northeast } \\
\text { cover of Ashanti Belt }\end{array}$ & $\begin{array}{l}\text { Mesothermal vein type, } \\
\text { alluvial }\end{array}$ & $\sim 4.7 \mathrm{~g} / \mathrm{t}$ & $\sim 0.2 \mathrm{Moz}$ & Griffis et al. (2002) \\
\hline Bogosu & $\begin{array}{l}\text { Southwestern Ghana, } 60-90 \mathrm{~km} \\
\text { northeast of Atlantic coastline }\end{array}$ & Mesothermal vein type & $\sim 2.0-5.3 \mathrm{~g} / \mathrm{t}$ & $>2.5 \mathrm{Moz} \mathrm{Au}$ & $\begin{array}{l}\text { Mumin et al. (1994); } \\
\text { Oberthür et al. (1997); } \\
\text { Griffis et al. (2002); } \\
\text { Allibone et al. (2002) }\end{array}$ \\
\hline Dabokrom & $15 \mathrm{~km}$ northwest of Tokaradi & $\begin{array}{l}\text { Mafic-hosted } \\
\text { mineralisation }\end{array}$ & $\sim 3-15 \mathrm{~g} / \mathrm{t}$ & $\sim 0.7 \mathrm{Moz}$ & Griffis et al. (2002) \\
\hline Golden Ridge & $\begin{array}{l}130 \mathrm{~km} \text { northwest of Accra, } \\
\text { northeastern margin of Ashanti Belt }\end{array}$ & Mesothermal vein type & NA & NA & Griffis et al. (2002) \\
\hline Iduapriem & $\begin{array}{l}\text { Southern end of Tarkwa district, } \\
\text { southern hill of Tarkwa syncline }\end{array}$ & Palaeoplacer type & $\sim 1.2-1.7 \mathrm{~g} / \mathrm{t}$ & $\sim 2 \mathrm{Moz} \mathrm{Au}$ & Griffis et al. (2002) \\
\hline Konongo & $\begin{array}{l}\text { Northeastern extremity of Ashanti } \\
\text { Belt, } 70 \mathrm{~km} \text { northeast of Obuasi }\end{array}$ & Mesothermal vein type & $\sim 1.1-3.9 \mathrm{~g} / \mathrm{t}$ & $\sim 0.9 \mathrm{Moz}$ & $\begin{array}{l}\text { Oberthür et al. (1997); } \\
\text { Griffis et al. (2002) }\end{array}$ \\
\hline Kubi & $\begin{array}{l}\text { Western margin of Ashanti Belt, } \\
6 \mathrm{~km} \text { northeast of Dunkwa }\end{array}$ & Mesothermal vein type & $\sim 6 \mathrm{~g} / \mathrm{t}$ & $\sim 0.8 \mathrm{Moz}$ & Griffis et al. (2002) \\
\hline Mampon-Aboronye & $\begin{array}{l}20 \mathrm{~km} \text { southwest of Dunkwa, } \\
\text { western flank of Ashanti Belt }\end{array}$ & Mesothermal vein type & $\sim 5.5 \mathrm{~g} / \mathrm{t}$ & $\sim 0.4 \mathrm{Moz}$ & Griffis et al. (2002) \\
\hline Nkran Hill & $40 \mathrm{~km}$ west-northwest of Obuasi & $\begin{array}{l}\text { Mesothermal vein type; } \\
\text { Granitoid type }\end{array}$ & $\sim 2.2 \mathrm{~g} / \mathrm{t}$ & $>2.5 \mathrm{Moz} \mathrm{Au}$ & Griffis et al. (2002) \\
\hline Nkroful & $\begin{array}{l}15 \mathrm{~km} \text { northwest of Axim, west of } \\
\text { Ashanti Belt, Kumasi Basin }\end{array}$ & $\begin{array}{l}\text { Mesothermal vein type, } \\
\text { alluvial }\end{array}$ & $<4 \mathrm{~g} / \mathrm{t}$ & NA & Griffis et al. (2002) \\
\hline Obuasi & $\begin{array}{l}\text { Ashanti Region, } 60 \mathrm{~km} \text { south of } \\
\text { Kumasi, } 160 \mathrm{~km} \text { northwest of Accra }\end{array}$ & $\begin{array}{l}\text { Mesothermal vein type; } \\
\text { Granitoid type }\end{array}$ & $\sim 2.6-10.1 \mathrm{~g} / \mathrm{t}$ & $>60 \mathrm{Moz}$ & $\begin{array}{l}\text { Bowell et al. (1990); } \\
\text { Oberthür et al. (1997); } \\
\text { Osae et al. (1999); } \\
\text { Yao and Robb (2000); } \\
\text { Fougerouse } \text { et al. (2015) }\end{array}$ \\
\hline Prestea & $\begin{array}{l}\text { Southwestern Ghana, } 60-90 \mathrm{~km} \\
\text { northeast of Atlantic coastline }\end{array}$ & Mesothermal vein type & $\sim 3.4 \mathrm{~g} / \mathrm{t}$ & $>7.2 \mathrm{Moz} \mathrm{Au}$ & $\begin{array}{l}\text { Mumin et al. (1994); } \\
\text { Oberthür et al. (1997) }\end{array}$ \\
\hline Salman & $\begin{array}{l}15 \mathrm{~km} \text { north of Axim, western } \\
\text { boundary of Ashanti Belt }\end{array}$ & Mesothermal vein type & $\sim 1.6-2.3 \mathrm{~g} / \mathrm{t}$ & $\sim 1.2 \mathrm{Moz}$ & Griffis et al. (2002) \\
\hline
\end{tabular}


Table 1 contd...

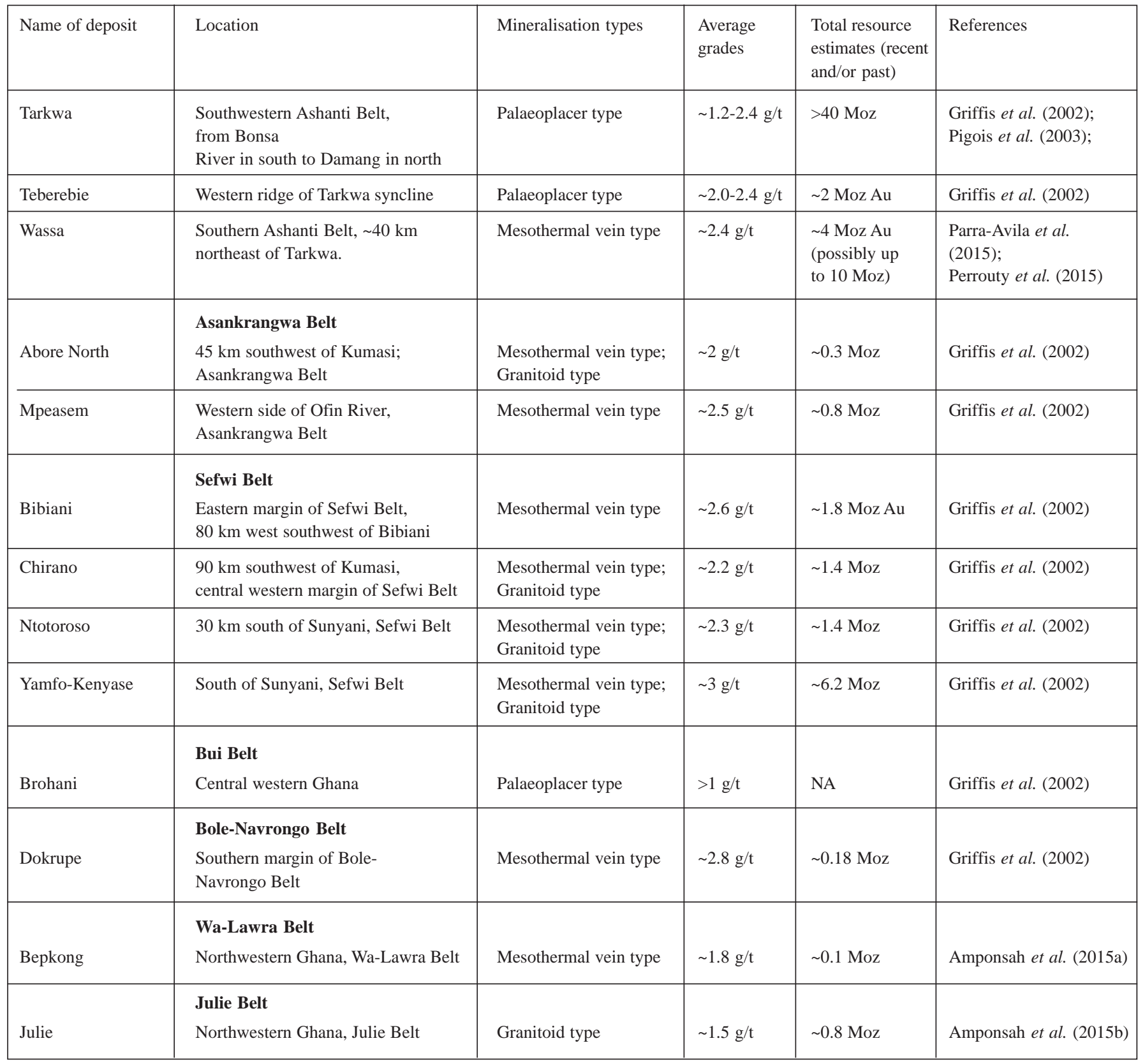

mineralisation is restricted to the northeast striking Ashanti fault zone where the Ashanti thrust fault is subdivided into mineralised splay faults that consist of graphitic shears (Fougerouse et al., 2015) (Fig. 5A).

The first subtype of mesothermal quartz vein and quartz veinassociated sulphide type deposits, namely the quartz vein gold deposits, have multiple stage (e.g. three generations at Wassa; Perrouty et al., 2015), extensive, steeply dipping (Fig. 5B) vein systems. The systems vary from thin $(<2 \mathrm{~m})$, discrete veins in parallel sets (e.g. at Prestea), to broad stockwork systems where the veins can be as thick as $20 \mathrm{~m}$ to $55 \mathrm{~m}$. Generally the quartz vein-hosted gold mineralisation appears to be associated with the regional ductile to brittle D3 deformational event of northwest to southeast compression, as observed at Bepkong, Bogoso, Damang, Obuasi and Wassa. However, earlier quartz vein-hosted gold mineralisation associated with the D1 deformational event which caused folding of the Sefwi Group by north-south compression has been observed at Wassa (Griffis et al., 2002; Obuasi; Bibiani et al., 2002; Allibone et al., 2002b; Tunks et al., 2004; Amponsah et al., 2015a; Fougerouse et al., 2015; Perrouty et al., 2015).

Associated with the quartz vein systems is the second subtype of the Ashanti-type mineralisation, namely quartz vein-associated sulphide mineralisation which is charaterised by wide disseminated sulphide zones in the host rocks that can extend up to $100 \mathrm{~m}$ (e.g. at Prestea) into the host rock. Gold mineralisation in the disseminated sulphide zones is generally subeconomic and/or refractory (Griffis et al., 2002). However, at Obuasi it makes up more than $50 \%$ of the ore reserve (Fougerouse et al., 2013). The zones appear to occur as variably sized pods and are generally cut by quartz vein systems (Figs. 3 and 5C), indicating an earlier gold mineralisation stage for the disseminated sulphides (Griffis et al., 2002). The sulphide mineralisation appears to be associated with the regional extensional 
D2 deformation event (Fougerouse et al., 2013; 2015) but could also be coeval to the D3 event-associated quartz vein mineralisation (Oberthür et al., 1997).

The host rocks for mesothermal quartz vein and quartz veinassociated sulphide type mineralisation include: metasediments usually in proximity to graphitic/carbonaceous, siliceous or manganiferous chemical sedimentary rocks; mafic volcanic rocks; and belt intrusions (Griffis et al., 2002). These host rocks, excluding the belt intrusions, comprise the volcano-sedimentary Birimian Supergroup. For example, at Obuasi the gold mineralisation is hosted in the metasedimentary Kumasi Group lithologies (Fougerouse et al., 2015) whereas at Wassa, gold mineralisation is hosted in the volcanosedimentary Sefwi Group lithologies (Perrouty et al., 2015). However, mesothermal gold mineralisation can also occur in Tarkwaian Group conglomerates, sandstones and phyllites, as has been observed at Damang Gold Mine (Tunks et al., 2004).

\section{Tarkwaian palaeoplacer mineralisation}

Economic gold concentrations occur in the quartz pebble conglomerate of the Banket Series of the Tarkwaian Group (Fig. 4).
The mineralisation is generally considered to be of modifiedpalaeoplacer type. The type locality for this deposit type is the Tarkwa district, located in the southwestern extremity of the Ashanti Belt (Fig. 1). Deposits in Ghana (Fig. 1; Table 1) where this is an important mineralisation type include Abosso-Damang, Iduapriem, Tarkwa and Teberebie. This mineralisation type has been estimated to have a total gold inventory of approximately $550 \mathrm{t}(\sim 16 \mathrm{Moz})$ in Ghana (Pigois et al., 2003; Tunks et al., 2004; Klemd et al., 1993; Griffis et al., 2002; Milési et al., 1991; Yao et al., 2001).

The gold-bearing conglomerates of the Banket Series crop out in two areas in Ghana (Fig. 1): from the southwest of the country to the edge of the Volta Basin in the northeast, a region that is $250 \mathrm{~km}$ long and $16 \mathrm{~km}$ wide; and in west central Ghana over an area that is $140 \mathrm{~km}$ long and $0.8 \mathrm{~km}$ wide (Kesse, 1990). The Banket Series is marked by a number of well packed quartz pebble conglomerates (Fig. 6A) that were deposited from southeasterly to northwesterly flowing rivers (Oberthür et al., 1995). The mature and clean nature of the conglomerates and interbedded sandstones suggest that reworking took place (Kesse, 1990). The conglomerates have been subjected to low grade metamorphism producing chlorite-sericite assemblages (Kesse, 1990).
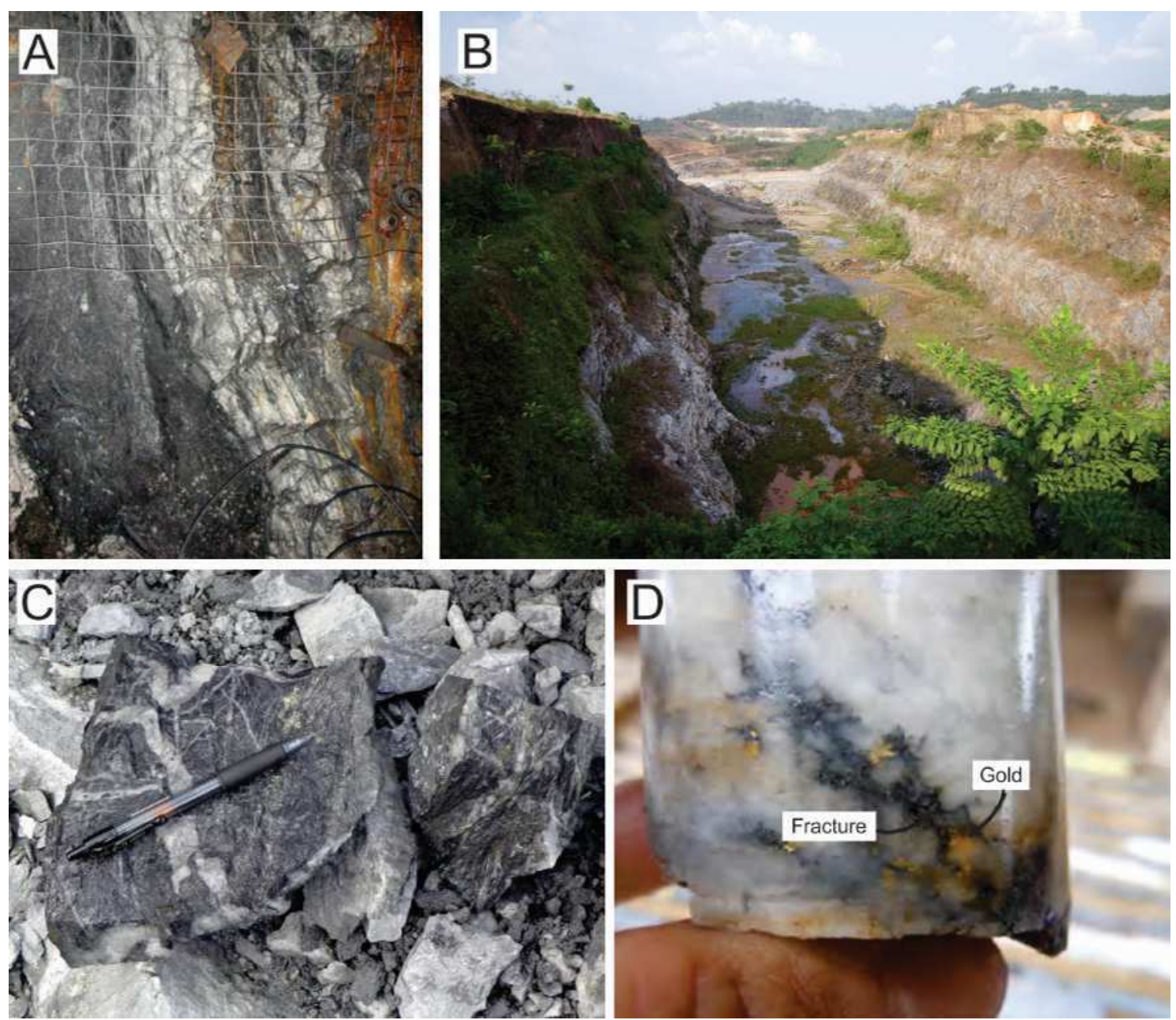

Figure 5: Photographs illustrating some features of Birimian mesothermal gold mineralisation from gold deposits in Ghana. A) Quartz veins and mineralisation in graphitic sheared faults at Obuasi Mine (photograph courtesy of AngloGold-Ashanti). B) Wassa Mine's B ore shoot illustrating the narrow and steeply dipping nature of the mined out mineralisation (photograph courtesy of Stephane Perrouty). C) Arsenopyrite in the metasediments surrounding the quartz veins at Obuasi Mine (photograph courtesy of AngloGold-Ashanti). D) Visible gold occurring in fractures within a quartz vein at Obuasi Mine (photograph courtesy of AngloGold-Ashanti). 
Gold occurs within four conglomeratic reefs in the Banket Series: the footwall Sub-basal reef; the Main (Basal) Reef; the West (Middle) Reef; and the hanging wall Breccia Reef (Fig. 4) (Klemd et $a l .$, 1993). The best gold grades occur in the Main (Basal) Reef, although the overlying conglomerates contain significant gold and the interbedded cross-bedded quartzites (Fig. 6B) also contain some gold (Griffis et al., 2002). The conglomeratic sequence varies in width in the Tarkwa syncline of the Ashanti belt from 30 to $45 \mathrm{~m}$ in the east to 60 to $75 \mathrm{~m}$ in the west. The conglomerate occurs as lenses, individually between 600 and $1,000 \mathrm{~m}$ long and 100 to $150 \mathrm{~m}$ wide (Griffis et al., 2002).

\section{Hydrothermal gold mineralisation in basement-type granitoids}

Due to the revival in Ghana's gold industry in the 1980s, increased exploration led to the discovery of gold deposits hosted in
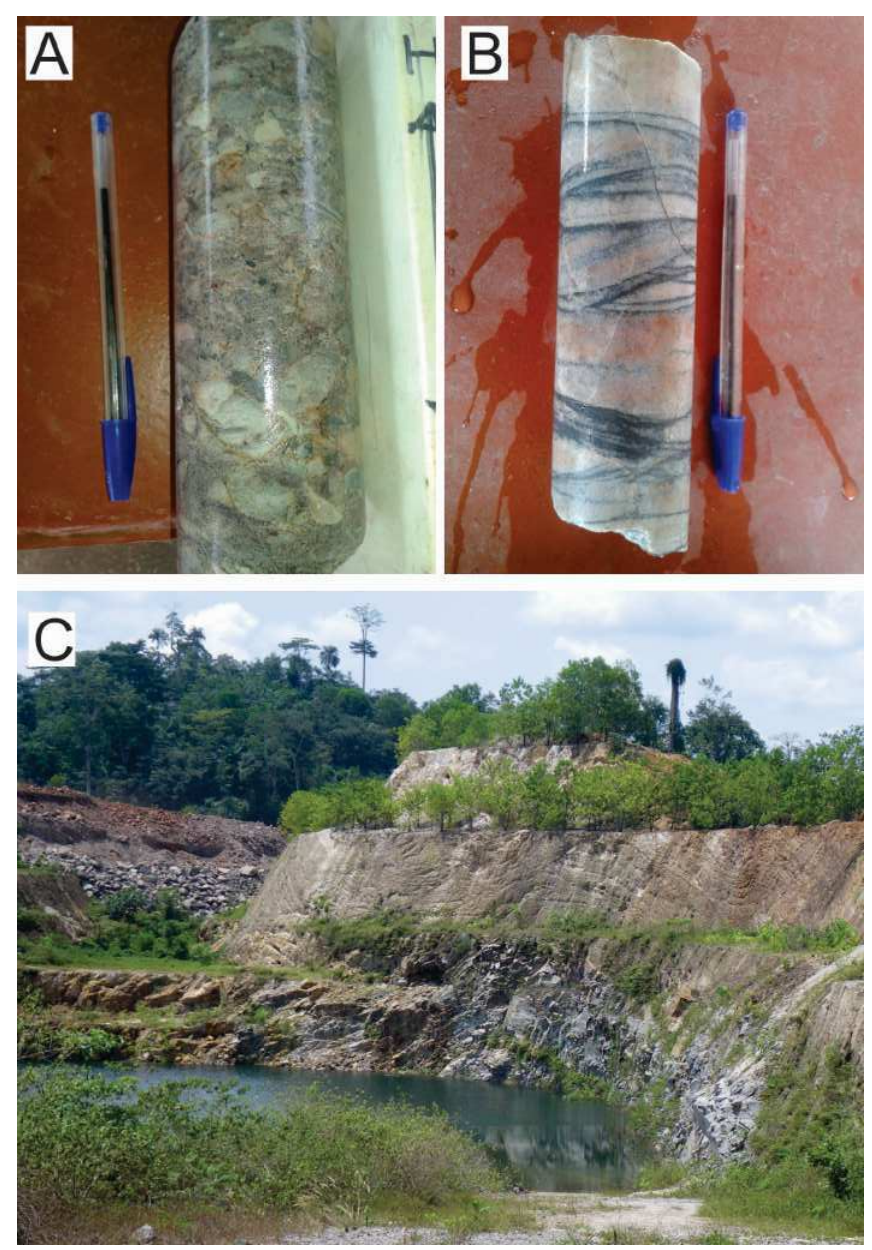

Figure 6: Photographs illustrating some features of Tarkwaian palaeoplacer gold mineralisation from gold deposits in Ghana. A) A well-packed quartz pebble conglomerate from the Banket Formation at Iduapriem Mine (photograph courtesy of AngloGoldAshanti). B) Cross-bedded quartzite, with dark layers of haematite on bedding and cross bedded surfaces, interbedded with the conglomerates of the Banket Formation at Iduapriem Mine (photograph courtesy of AngloGold-Ashanti). C) Open folding in Tarkwaian sedimentary rocks caused by the D3 deformational event at Damang Mine (photograph courtesy of Stephane Perrouty).
Palaeoproterozoic Birimian belt and basin granitoids which occur across southwest, west and northwest Ghana. Gold deposits in Ghana where this mineralisation type occurs (Table 1; Fig. 1) include Ayanfuri, Chirano, Julie, Nkran Hill, Ntoroso, Obuasi and Yamfo. This mineralisation type has been estimated to have a total gold inventory of approximately $100 \mathrm{t}(\sim 2.9 \mathrm{Moz})$ in Ghana, but could be even higher with more recent discoveries such as the granitoid-hosted Julie gold deposit in northwestern Ghana (Yao and Robb, 2000; Yao et al., 2001; Griffis et al., 2002; Amponsah et al., 2015b).

Mineralised granitoids are generally smaller than the unmineralised ones, are granodioritic to granitic in composition and occur as small, steeply dipping stockworks and sulphide disseminations that are concordant with the regional faults and shears that strike northeast and east (Oberthür et al., 1995; Yao and Robb, 2000; Yao et al., 2001; Amponsah et al., 2015b). They have generally intruded Birimian metasediments (for example phyllites at Obuasi; Yao and Robb, 2000) and mineralisation occurs in both the granitoids and metasediments (Griffis et al., 2002). The overall size and shape of the gold mineralised granitoid ore bodies in Ghana are generally poorly constrained. However, at the Julie deposit in northwestern Ghana, the granitoid-hosted ore deposit consists of two plunging lenticular shaped swarms of orientated veins within shear zones that vary in thickness between $20 \mathrm{~m}$ and $50 \mathrm{~m}$, with a measured strike extent of up to $100 \mathrm{~m}$ (Amponsah et al., 2015b). The gold mineralisation occurs within and around quartz veins and stockworks in altered zones that show two (Yao and Robb, 2000) to three (Amponsah et al., 2015b) cross cutting generations of veining. Not all vein generations are necessarily associated with gold mineralisation. The veins fill extensional fractures and are deformed (Yao et al., 2001).

\section{Mineralogy of gold occurrences}

\section{Mesothermal quartz vein and quartz vein- associated sulphide type mineralisation}

The mesothermal quartz vein gold ores typically border graphitic shear zones (Fig. 5A) and contain variable but high grades of visible gold in thick quartz veins (Fougerouse et al., 2015). The visible gold occurs in micro-fractures that overprint the quartz veins (Fougerouse et al., 2015) (Fig. 5D) and is generally intergrown with polymetallic sulphides (Oberthür et al., 1995). The quartz is medium to dark grey in colour and may contain small amounts of ankerite and host rock fragments in unmineralised parts. Along with visible gold and polymetallic sulphides, muscovite occurs in the mineralised microfactures (Griffis et al., 2002; Fougerouse et al., 2015). Rare occurrences of aurostibite, bismuthotellurides and auriferous lollingite are also observed in quartz vein ores (Oberthür et al., 1995).

The quartz vein-associated disseminated sulphide ores are dominated by arsenopyrite ( 60-95\%; Fig. 5C) and also contain pyrite, pyrrhotite, marcasite, chalcopyrite and rare native gold (Fougerouse et al., 2015). Larger arsenopyrite grains can be zoned with gold-rich rims and gold-poor cores. The gold is locked in the sulphide lattice of mostly arsenopyrite but also pyrite (Oberthür et al., 1994; Griffis et al., 2002; Fougerouse et al., 2015) and is generally refractory (i.e. cannot be recovered by cyanidation), although some deposits (e.g. Nkran Hill, Chirano, Ntotoroso and Ayanfuri) contain significant native gold (Griffis et al., 2002). 
Alteration envelopes of variable sizes occur around the quartz vein systems. Alteration types include silicification, chlorite and carbonate alteration, sericitisation and albitisation. The disseminated sulphide zones surrounding the quartz vein systems are generally highly silicified and are therefore thought to form part of the alteration envelopes (Griffis et al., 2002).

\section{Tarkwaian palaeoplacer mineralisation}

The conglomerates that host the gold mineralisation in the Banket Series are oligomictic, well-sorted and consist mostly of vein-quartz pebbles (>90\%) and subordinate schist and quartzite pebbles (Kesse, 1985; 1990; Milési et al., 1991; Klemd et al., 1993) (Fig. 6A). The matrix is made up of quartz and heavy mineral sands with the latter comprising hematite with some ilmenite, magnetite and rutile. In the Main Reef, which has the highest gold contents, the gold is concentrated in the basal $20 \mathrm{~cm}$ and the highest gold contents are associated with well-packed hematite- and magnetite-rich horizons or payshoots, parallel to palaeochannels. The gold shows two modes of occurrence: as fine (10-60 $\mu \mathrm{m})$ grains of free gold within the matrix of the conglomerate, associated with the heavy mineral sands; and as intergrowths, overgrowths and inclusions with authigenic ilmenite/ rutile aggregates, magnetite and hematite (Kesse, 1990; Eisenlohr, 1992; Klemd et al., 1993). The gold has a silver-depleted composition (Eisenlohr, 1992).

Quartz veins cross cut the mineralised conglomerates in places and can contain minor gold and pyrite mineralisation (Eisenlohr, 1992) and sulphidised haloes (Klemd et al., 1993). In addition to commonly occurring close to quartz veins, sulphides can also occur in proximity to the faults and dykes cross cutting the conglomerates (Eisenlohr, 1992).

\section{Hydrothermal gold mineralisation in basement-type granitoids}

The ore mineral assemblage encountered in the quartz veins and associated alteration zones in granitoid-type gold mineralisation includes mainly pyrite and arsenopyrite, with minor chalcopyrite, sphalerite and galena. Pyrite is the most abundant sulphide and two generations, namely early coarse and late fine grains and aggregates occur. The gold mostly occurs as free gold micro-inclusions within pyrite and arsenopyrite but can also occur as larger grains within fractures or on the edges of pyrite. Minor solid solution or submicroscopic gold also occurs in pyrite (Oberthür et al., 1995; Yao and Robb, 2000; Amponsah et al., 2015b).

Alteration zoning is present in the granitoids surrounding the quartz veins and decreases from the ore zones outwards. The strongest alteration within and directly surrounding mineralisation, comprises a mineral assemblage of sericite, quartz, ankerite, calcite, tourmaline, rutile, pyrite and arsenopyrite. The original textures of the granitoid are destroyed and the rocks have a bleached appearance due to carbonatisation. The size of the alteration halo is variable and, for example, is much larger at Julie ( $\sim 50 \mathrm{~m}$; Amponsah et al., 2015b) than at Obuasi ( 1 m; Yao and Robb, 2000). Further away from the mineralised zone the alteration assemblage is characterised by albite, sericite, calcite, chlorite, pyrite and rutile and then finally by chlorite, epidote and biotite. The latter assemblage is considered to be a greenschist facies metamorphic overprint (Yao and Robb, 2000; Amponsah et al., 2015b).

\section{Age of gold mineralisation \\ Mesothermal gold mineralisation in rocks of the Birimian Supergroup and granitoids}

Detrital zircons from Birimian metasandstone at Obuasi (thought to be of the Kumasi Group) have been dated at a minimum age of $2155 \pm 2 \mathrm{Ma}$ (Oberthür et al., 1998) and provide a maximum age for mesothermal gold mineralisation in the Birimian Supergroup metasediments. The age of gold mineralisation in belt granitoids at Sakpa Mine in the Bole-Navrongo belt, has been determined at between $2110 \pm 32 \mathrm{Ga}$ and $2133 \pm 21 \mathrm{Ma}$, using uranium-lead (U$\mathrm{Pb}$ ) on hydrothermal rutile (Yao and Robb, 1999). For basin granitoids at the Obuasi and Ayanfuri mines, the age of gold mineralisation has been determined at between $2086 \pm 4$ and $2098 \pm 7 \mathrm{Ma}$ using $\mathrm{Pb}-\mathrm{Pb}$ on hydrothermal rutile and galena (Oberthür et al., 1998). These ages of mineralisation post-date the granitoid emplacement by approximately 5 to $30 \mathrm{Ma}$ (Yao et al., 2001). The similarity of the quartz vein-associated gold mineralisation in the granitoids and the Birimian metasediments, as well as their close geological association, therefore suggests that the age of mineralisation in the granitoids is close to the minimum age of mineralisation in the Birimian metasediments. In addition, $\mathrm{Pb} / \mathrm{Pb}$ model ages of quartz vein-hosted galena, bournonite and gold at Ashanti Mine, gave a range of approximately 2120 to $2080 \mathrm{Ma}$ (Höhndorf et al., 1994; Oberthür et al., 1995). Mesothermal gold mineralisation in the Birimian metasediments therefore appears to be constrained between approximately $2155 \mathrm{Ma}$ and $2080 \mathrm{Ma}$. This age range pre-dates and also overlaps the 2130 to 1980 Ma Eburnean orogeny (Feybesse $e t$ al., 2006; Perrouty et al., 2012), which is reconcilable with D2 (preEburnean) disseminated sulphide- and D3 (Eburnean) quartz veinassociated mesothermal gold mineralisation.

However, at Wassa Mine the mesothermal gold mineralisation is hosted in the lower Sefwi Group and appears to be associated with the D1 Eoeburnean deformational event. As mentioned in an earlier section, D1 synorogenic granitoids intruded between 2187 and 2158 Ma (Perrouty et al., 2012; 2015), implying that this is the age range for an earlier mesothermal gold mineralisation episode at Wassa.

\section{Tarkwaian palaeoplacer mineralisation}

The deposition of the Tarkwaian Group occurred between approximately $2133 \mathrm{Ma}$ and $2097 \mathrm{Ma}$, which will also be the depositional age range for any palaeoplacer gold. With regards to the mesothermal quartz vein-associated gold mineralisation that overprinted the Tarkwaian palaeoplacer mineralisation, U-Pb ages on hydrothermal xenotime suggest that the mesothermal mineralisation occurred at $2063 \pm 9 \mathrm{Ma}$ (Pigois et al., 2003). This is younger than the mineralisation age range for Birimian Supergroup-hosted mesothermal gold mineralisation discussed in the previous section (2155-2080 Ma), but still falls within the age range of the Eburnean orogeny (2130-1980 Ma).

\section{Genetic models for gold mineralisation}

\section{Mesothermal quartz vein and quartz vein- associated sulphide type mineralisation}

The association of Ashanti type mineralisation with deformational 
fabrics and features indicates that more than one episode of gold mineralisation occurred in deposits hosted in the Birimian Supergroup of Ghana. The majority of deposits show evidence for the quartzvein associated sulphide ores to have formed during the D2 extensional event and the quartz vein free gold ores to have formed during the Eburnean D3 compressional event (e.g. Allibone et al., 2002b; Tunks et al., 2004; Amponsah et al., 2015a; Fougerouse et al., 2015; Perrouty et al., 2015). However, examples of quartz vein free gold ores associated with the Eoeburnean D1 compressional event are also encountered (Perrouty et al., 2015). This deformational association, as well as the location of gold mineralisation close to major shear zones (Oberthür et al., 1995) and fault systems (e.g. the Ashanti fault; Fougerouse et al., 2015), termed "structural corridors" (Griffis et al., 2002), also highlight the importance of structural controls on the development of gold mineralisation. Hydrothermal fluids were therefore most likely moved from a deeper crustal origin into sites of mineralisation along shear zones and faults in the granitoids and Birimian lithologies by Eoburnean and Eburnean orogenic stress and strain cycling through seismic pumping, or a "fault valve" fluid flow model (Sibson et al., 1975; 1988; reviewed by Robb, 2005).

Fluid inclusion studies indicate that the quartz vein-mineralising fluids were $\mathrm{CO}_{2}$-dominated gas mixtures with $\mathrm{N}_{2}$ and minor $\mathrm{CH}_{4}$ (Oberthür et al., 1995). Although $\mathrm{H}_{2} \mathrm{O}$ is absent in the fluid inclusions, evidence from alteration mineral compositions (Mumin et al., 1996; Manu et al., 2013) and fluid inclusions in Birimian granitoid-hosted quartz vein gold mineralisation (Oberthür et al., 1995; Yao and Robb, 2000) suggest that $\mathrm{H}_{2} \mathrm{O}$ was also dominant in the fluids at least during some stages of fluid evolution. The fluids were deep-seated and of magmatic or metamorphic origin and the veins formed at a temperature of $400 \pm 50^{\circ} \mathrm{C}$ and fluid pressures of $2 \mathrm{kbar}$ to $5 \mathrm{kbar}$ (Oberthür et al., 1995). For Bogosu and Prestea, Mumin et al. (1996) proposed that the fluids were of metamorphic origin only. Temperatures derived from the ankerite-siderite composition geothermometer from carbonates occurring in mineralised rocks at Bogosu and Prestea, indicate that gold mineralisation occurred over a temperature range of $340^{\circ} \mathrm{C}$ to $140^{\circ} \mathrm{C}$ at crustal depths of $7 \mathrm{~km}$ to $11 \mathrm{~km}$. The lack of chemical re-equilibration between the ore fluid and country rock also suggests that the fluid ascent from its deep source to the shallower mineralisation sites was rapid. Decrease in temperature, pressure and $\mathrm{CO}_{2}-\mathrm{H}_{2} \mathrm{O}$ immiscibility in the hydrothermal fluids, is thought to have caused the precipitation of the ore minerals (Mumin and Fleet, 1995; Mumin et al., 1996; Manu et al., 2013).

\section{Tarkwaian palaeoplacer mineralisation}

Observations and evidence in support of a sedimentological control (of detrital or palaeoplacer origin) for the gold in the Banket Series are as follows: the gold payshoots follow palaeochannels; economic gold concentrations are associated with other heavy mineral concentrations; gold occurrences are unrelated to quartz veins and sulphidisation (Klemd et al., 1993; Oberthür et al., 1995); and the gold is generally depleted in silver (Eisenlohr, 1992; Klemd et al., 1993). Interpretations of the depositional environment include: alluvial fans on a piedmont surface with later braided river streams from the east dispersing the alluvial sediment (Sestini, 1973; Kiessling, 1997); and braided tributary channels originating from the east and joining up with a main trunk channel flowing to the north (Strogen, 1991).

The source of the placer gold in the Banket Series is a matter of debate. Where early authors considered the mesothermal quartz vein- associated gold of the Birimian Supergroup as the source for Tarkwaian palaeoplacer gold (e.g. Junner et al., 1942; Kesse, 1984), it was later determined that the D2 and D3 deformational events, with which the mesothermal gold mineralisation is associated, also overprinted the Banket Series (Milési et al., 1991; Eisenlohr, 1992) (Fig. 6C). The detrital gold in the Banket Series was therefore already deposited when the D2 and D3 events helped concentrate mesothermal gold mineralisation in the metasediments of the Birimian Supergroup. The southeast to northwest palaeocurrent directions at Tarkwa also make it impossible for the Birimian gold mineralisation in the area to have been the gold source for the Banket Series in this region (Oberthür $e t$ al., 1995). The occurrence of Eoburnean (D1 deformational event) gold mineralisation in the Sefwi Group lithologies at Wassa, could be indicative of an older gold source for the paleoplacers (Perrouty et al., 2015).

It is important to note that some gold mineralisation occurs within the quartz veins that cross cut the conglomerates, suggesting some gold remobilisation by fluids during deformation and metamorphism (Eisenlohr, 1992), similar to the modified placer mineralisation model for the Witwatersrand gold reefs of South Africa (e.g. Els, 1991; Robb et al., 1997; Frimmel and Minter, 2002; Hayward et al., 2005).

\section{Hydrothermal gold mineralisation in basement-type granitoids}

In addition to the geological setting, geochemistry, geochronology and mineral assemblages, quartz vein fluid inclusion studies have been important in constraining the genetic history of gold mineralisation in the granitoid bodies (e.g. Yao and Robb, 2000; Yao et al., 2001; Amponsah et al., 2015b). The composition of the granitoid-hosted fluid inclusions in the Ashanti Belt is comparable to those in mesothermal gold deposits in Ghana (Yao et al., 2001), suggesting a genetic link between the two.

The mineralised Palaeoproterozoic belt and basin granitoids are considered to be good sites for gold mineralisation due to their brittle nature during deformation and would have provided good conduits for fluid flow (Yao et al., 2001). For Obuasi, Yao and Robb (2000) proposed that the gold mineralisation in the granitoids was caused by a metamorphic, reduced, low-salinity $\mathrm{H}_{2} \mathrm{O}-\mathrm{CO}_{2}-\mathrm{NaCl}$ fluid, in a brittle deformational regime during the waning stages of the Eburnean orogeny at approximately $2100 \mathrm{Ga}$. A low-salinity $\mathrm{H}_{2} \mathrm{O}-\mathrm{CO}_{2}$ fluid was also proposed by Oberthür et al. (1995). Pressure and temperature conditions were likely $1 \mathrm{kbar}$ to $3 \mathrm{kbar}$ and $180^{\circ} \mathrm{C}$ to $350^{\circ} \mathrm{C}$, respectively, and gold deposition was thought to have been induced by $\mathrm{H}_{2} \mathrm{O}-\mathrm{CO}_{2}$ fluid immiscibility and/or sulphidisation during alteration. Fluids characterised by $\mathrm{CO}_{2}-\mathrm{N}_{2} \pm \mathrm{CH}_{4}$ could also have been involved with gold mineralisation, as observed in fluid inclusions at Sansu mine (Yao et al., 2001).

The genetic model proposed by Amponsah et al. (2015b) for the granitoid-hosted gold mineralisation at the Julie deposit in northwestern Ghana show some similarities and differences to those proposed for the Ashanti Belt (Yao and Robb, 2000; Yao et al., 2001). A similar $\mathrm{H}_{2} \mathrm{O}-\mathrm{CO}_{2}-\mathrm{NaCl}$ mineralising fluid of moderate to low salinity that underwent liquid immiscibility in a brittle to ductile deformational regime is also proposed for the Julie deposit. However the temperature and pressure of the fluid during immiscibility are estimated to have been $220^{\circ} \mathrm{C}$ and less than $1 \mathrm{kbar}$, respectively (Amponsah et al., 2015b), towards the lower range of that proposed 
for the Ashanti Belt. The most notable difference in the genetic models for the Ashanti and Julie Belts, is the timing of gold mineralisation. The mineralised veins at the Julie deposit are associated with the $\mathrm{D}_{\mathrm{J} 1}$ shear zone (Amponsah et al., 2015b) that likely corresponds to the D1 event in the Ashanti Belt, suggesting that gold mineralisation occurred earlier in the tectonic history of the Julie Belt than it did in the Ashanti Belt.

\section{Gold exploration in Ghana}

The geographical situation of Ghana divides the country into a tropical rain forest belt in the south that transitions northwards into tropical savannah. Most of the country's gold production has come from the south, with only minor prospects discovered to date in the northwestern part of the country.

The wet tropical climate has resulted in deep chemical weathering of the bedrock in both the rain forest and the savannah areas, with very little fresh rock outcrop exposed. There is no record of how the famous and rich Ashanti and related gold deposits were discovered, but it can be assumed that the early gold prospectors simply dug pits and trenches into any gold showings found by chance at surface. If gold was struck, the exploration diggings turned into small artisanal mines and were worked until the ore ran out. Such artisanal prospecting and mining continue to this day in parts of Ghana.

With Western colonisation and the establishment of industrialscale mining (discussed above) by companies such as Ashanti Goldfields Corporation and Tarkwa Goldfields Limited, more systematic exploration was carried out to increase ore resources near existing mining operations, and to discover new deposits. Early prospecting took the form of pitting and trenching "on trend" of existing deposits, followed by drilling, when gold assays of soil and rock samples showed positive results. This form of prospecting indirectly recognised that linear geological structures controlled some of the mineralisation.

Modern exploration methods, especially for completely hidden ore deposits, developed alongside the systematic study of the types of gold mineralisation, as reviewed in this paper. The physical and chemical characteristics of the ore deposits, together with the weathering regime, determine the optimum exploration techniques that will increase the chances of locating deeply buried deposits. With the advent of the space age, remote sensing techniques using satellite data have played an increasingly important role in regional exploration (Owusu et al., 2006; Kwang et al., 2014).

A modern exploration programme will be fully integrated, taking into account all available geoscientific data sets to focus targeting (Robert et al., 2007; Kuma et al., 2010; Magalhães and Filho, 2012). Geological, geophysical and geochemical information will be overlain, using geographic information systems (GIS) software, on topographic maps and satellite imagery, to tease out the features that may indicate the location of an ore deposit.

The importance of Ghana as a gold producing country is emphasised by the continued study and re-interpretations of the wellknown deposits such as Obuasi and Tarkwa (Allibone et al., 2002a; 2002b; Perrouty et al., 2012; 2014; Fougerouse et al., 2015). A full understanding of the types of mineralisation is the foundation for effective exploration.

A symposium was held in May 1990 in Accra, on gold exploration in the tropical rain forest belts of southern Ghana (Barning, 1990). Amongst others, papers were presented on geophysical prospecting in the search for gold in the Ashanti area, and the use of geochemistry in the exploration for gold. Five lode gold case studies were presented, together with two on alluvial gold deposits. The interested reader will find Barning (1990) of use with regards to the conventional exploration techniques that are still important in modern exploration (Nude and Arhim, 2009; Arhim, 2013; Tisbaoh and Grant, 2009; Wemegah et al., 2015).

The availability of powerful computers and the development of sophisticated GIS programmes have allowed the rapid merging of diverse geoscientific data sets that are being interpreted to focus mineral detection (Porwal and Carranza, 2015). One such attempt was carried out by Carranza et al. (2009) who mapped the prospectivity and estimated the number of undiscovered prospects for lode gold in the southwestern Ashanti Belt in Ghana (Fig. 7). They carried out mineral prospectivity mapping (MPM) and mineral resource assessment (MRA), two distinct predictive modelling methods for analysing geological and mineral occurrence data with a view to facilitating strategic mineral exploration over the study area. In combination, the two techniques predicted the occurrence of 37 to 40 undiscovered lode gold deposits in the southwestern Ashanti Belt (Carranza et al., 2009).

Another modern technique that is being used for broad strategic exploration of the Ashanti Belt is 3D modelling, as reported by Perrouty et al. (2014). Building on 2D remapping and re-interpretation

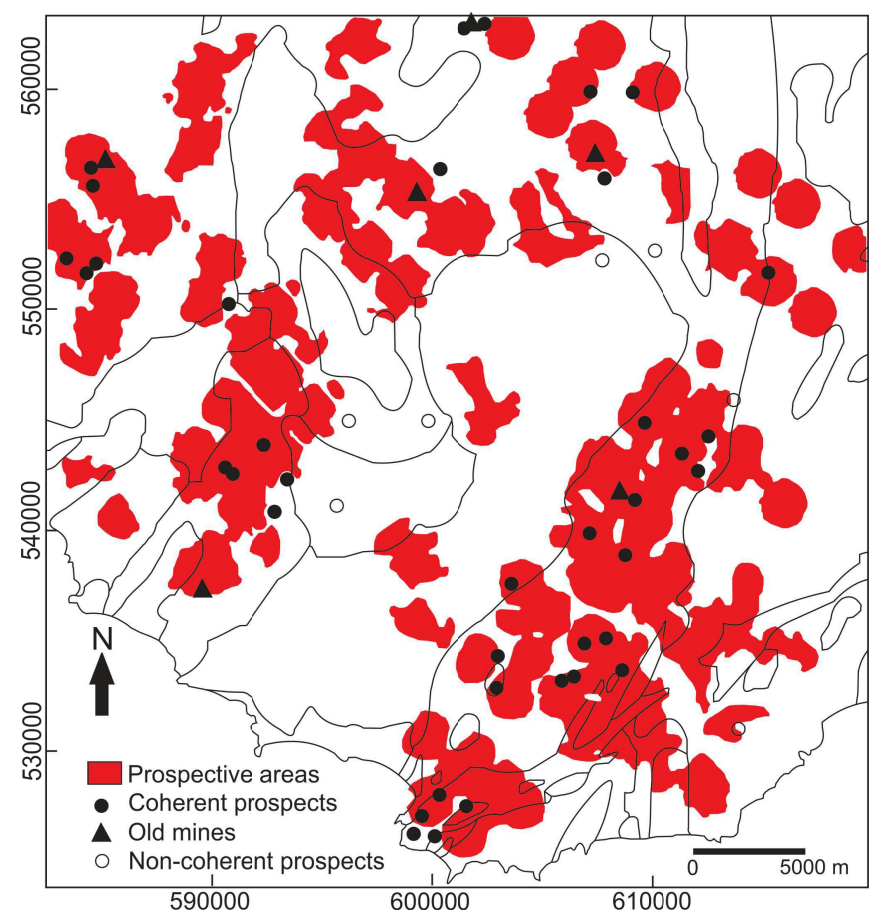

Figure 7: Map of predicted mesothermal gold prospective areas along with the locations of spatially coherent and non-coherent prospects as well as old mines from the southwestern Ashanti Belt (adapted from Carranza et al., 2009). Known gold deposits and prospects are used in training sets for the mineral prospectivity mapping. Spatially coherent deposits/prospects are those that show the best spatial correlation with the geological parameters (faults, lineaments) used in the analysis. The deposits/prospects that show poor correlation with the geological parameters are deemed spatially non-coherent. A detailed discussion is provided by Carranza et al. (2009). 
of the Sefwi Group (Perrouty et al., 2012), the authors used Geomodeller and Gocad software to build a 3D model of the Sefwi Group rocks. With the inclusion of 21 known gold occurrences in the model, it was noticed that $85 \%$ of the gold showings in the Sefwi Group occur within $1,500 \mathrm{~m}$ of the contact with the basaltic BV1 horizon. The authors thus infer that there is strong evidence for a lithostratigraphic control on the gold mineralisation in the Sefwi Group. They postulate that the BV1 unit could either have acted as a physical or chemical trap for gold-bearing hydrothermal fluids, or could have been the primary source of the gold (Perrouty et al., 2014). The latter interpretation has been suggested by other researchers and reviewed by Nyame (2013). Similar mapping and 3D modelling of structural controls on the Chirano gold occurrences was carried out by Kenworthy et al. (2009), in order to better delineate resources and exploration targeting near existing mines.

Once a target has been identified, drilling needs to be undertaken to, firstly, prove the existence and continuity of the potential ore body at depth, and, secondly, to delineate the potential mineral resources and ore reserves. Drilling is generally acknowledged as the most expensive stage of an exploration programme, and hence the information obtained from drilling must be maximised, especially from diamond drill core. The hole can be geophysically surveyed using a down-hole probe, and optically scanned to obtain structural data. The core in the core trays can be digitally scanned for archiving, and spectroscopically scanned to reveal details of mineralogy and alteration that may be associated with gold mineralisation. Such geophysical and geochemical logs complement the traditional geological logging method and facilitate rapid decision making during exploration.

In conclusion, one has to bear in mind the old maxim often quoted by the late Professor DA Pretorius, the founding director of the Economic Geology Research Unit (EGRU) (now Institute - EGRI) at the University of the Witwatersrand, Johannesburg, South Africa: "to search for elephants, you have to be in elephant country". When you explore for gold in Ghana (or elsewhere), you have to be in places that are favourable for gold mineralisation, otherwise you will be wasting time and money. Ghana is certainly elephant country, and it is a matter of time before some of the "undiscovered lode gold deposits" predicted by Carranza et al. (2009) are found.

\section{Future potential for gold in Ghana}

\section{Industrial-scale mining}

A comprehensive report released by the Ghana Chamber of Mines (GCM) and the International Council of Mining and Metals (ICMM) at the time of writing of this review (August 2015), emphasises the importance of gold mining to Ghana (GCM-ICMM, 2015). To quote: "The mining sector attracts more than half of all foreign direct investment, generates more than one-third of all export revenues, is the largest tax-paying sector and makes a significant contribution to GDP and employment." The compilers of the report aimed to provide an independent and objective evidence base regarding mining's past, present and possible future contributions to the Ghanaian economy and society. The annual gold production for 2013 for the seven largest gold producers, the latest data available at the time of writing, was also reported (Table 2).

The mining and fiscal statistics for seven of the largest gold mining operations in Ghana, which produced some $60 \%$ of the gold produced in 2013, are illustrated in graphs, and projections have been made to the year 2022. The compilers used data from 2010 to 2013 as a basis, and projected production out to 2022, averaging 1.896 million ounces per year for the 13 year period. Similar projections gave sales revenues of US\$2,517 million on average, with expenditures of US\$2,262 million. As with most projections, a number of assumptions had to be made, such as the future price of gold, working costs, etc. which impart a significant level of uncertainty to the statistics. Nevertheless the report is positive on the role that gold mining will be playing in Ghana's economy in the near future.

The GCM-ICMM report does not list the current gold resources of the seven mining companies operating in Ghana that were studied. It is thus instructive to ascertain whether these projected production figures can be sustained to 2022 by summing the latest available gold resources reported by the seven mining companies (Table 2). It is evident that there are sufficient gold resources reported by the seven studied companies to sustain mining to the year 2022. The GCMICMM report thus paints an overall realistic picture about the future of large-scale gold mining in Ghana.

One aspect arising out of this brief look into the future is the

Table 2: Annual gold production for 2013 and total gold resources reported by the seven gold mining companies studied in the GCM-ICMM 2015 report. Other than the GCM-ICMM 2015 report, the gold resources statistics are taken from Anglogold-Ashanti (2014), Endeavour Mining (2015), Gold Fields Limited (2015), Golden Star Resources (2015), Kinross Gold Corporation (2015), Newmont (2015) and Perseus Mining Limited (2015).

\begin{tabular}{|l|l|c|c|c|}
\hline Mining Company Name & Location in Ghana & $\begin{array}{c}\text { Annual Output } \\
2013 \text { (ounces) }\end{array}$ & $\begin{array}{c}\text { Total Resources } \\
\text { (ounces) }\end{array}$ & $\begin{array}{c}\text { Year } \\
\text { Reported }\end{array}$ \\
\hline Adamus Resources & Teluku-Bokazo and Nkrofu & 105,215 & $1,901,000$ & 2014 \\
\hline Anglogold Ashanti & Obuasi and Iduapriem & 239,052 & $33,730,000$ & 2013 \\
\hline Chirano Gold Mines & Chirano & 274,683 & $2,271,000$ & 2014 \\
\hline Gold Fields Ghana & Tarkwa and Damang & 785,421 & $14,800,000$ & 2014 \\
\hline Golden Star Resources & Prestea and Wassa & 330,807 & $6,653,000$ & 2014 \\
\hline Newmont Ghana & Ahafo and New Abirem & 699,366 & $5,660,000$ & 2014 \\
\hline Perseus Mining (Ghana) & Ayanfuri & 198,608 & $3,280,000$ & 2011 \\
\hline Total & & $2,633,152$ & $68,295,000$ & \\
\hline
\end{tabular}

Notes: (1) Adamus Resources has being taken over by Endeavour Mining.

(2) Annual output for 2013 from the GCM-ICMM Report, 2015. 
disparity between the production from the Anglogold Ashanti (AGA) mines and the reported mineral resources. This is due to the current suspension of mining operations and the re-configuration of the Obuasi mine by AGA. Obuasi alone accounts for 27.39 million ounces of the gold resource, and is expected to return to being a significant gold producer in the country by 2016 . This is strengthened by the announcement on 16 September 2015 that AGA and Randgold Resources Limited (RRL) have entered into an agreement to form a joint venture (JV) to redevelop and operate the Obuasi gold mine (Anonymous, 2015). The JV has a high probability of being successful, as RRL has a good track record of profitable and efficient gold mining in West Africa.

\section{Artisanal and small-scale mining}

Artisanal and small-scale mining (ASM) was the only producer of gold in Ghana prior to the twentieth century (Griffis et al., 2002). The GCM-ICMM report estimates that $36 \%(\sim 1 \mathrm{Moz})$ of the total gold produced in Ghana in 2013 came from ASM, a significant amount. This type of mining activity provides a livelihood to many people in some poorly developed African countries, and is a significant job provider in Ghana. The estimated gold production of approximately 1 million ounces in 2013 from ASM is significantly higher than estimates in 2000 of approximately 146,000 ounces (Griffis et al., 2002), indicating that this is a growing sector in Ghana's economy. The growing importance of the artisanal and small scale gold mining sector has also been illustrated by the shift of artisanal diamond miners to artisanal gold mining in recent years due to, among other reasons, decreasing industrial-scale diamond production in Ghana, the increasing cost of artisanal diamond mining due to stricter regulations on diamond production and export, as well as increasing gold prices from 2001 to 2011 (Nyame and Grant, 2012).

The socio-economic, legal and environmental impact of the artisanal and small scale gold miners in Ghana, have been significant. Socio-economic impacts include: the modest economic recovery of mining communities; the discovery of new gold deposits; the development of innovative ASM techniques; a net migration into mineral-rich regions; and increased security threats due to crime and police raids. The greatest legal impact has been attempts by Ghana's and other sub-Saharan African countries' governments, to formalise ASM (Nyame and Blocher, 2010). From an environmental point of view the increased use of mercury by artisanal miners for gold recovery is of great concern due to the associated environmental degradation (Nyame, 2010; Nyame and Grant, 2012; 2014).

Whether the recent level of informal production is sustainable is difficult to predict, but the fact that Ghana is richly endowed with many very small to world-class gold deposits strongly suggests that artisanal and small scale gold mining will form part of the Country's economy well into the future.

\section{Acknowledgements}

The Department of Geology at the University of Johannesburg, the Palaeoproterozoic Mineralisation Research Group (PPM) and the Department of Science and Technology (DST) and National Research Foundation (NRF) funded Centre of Excellence for Integrated Mineral and Energy Resource Analysis (CIMERA) are thanked for their funding and support. AngloGold-Ashanti, Stephane Perrouty and Nic Beukes are also thanked for providing photographs for this contribution. Mike Robertson and Frank Nyame are thanked for their constructive reviews of this contribution.

\section{References}

Adadey, K., Clarke, B., Théveniaut, H., Urien, P., Delor, C., Roig, J.Y. and Feybesse, J.L. (2009). Geological map explanation-Map sheet 0503 B (1:1 000 000), CGS/BRGM/Geoman. Geological Survey Department of Ghana (GSD), No MSSP/2005/GSD/5a.

Addy, S.N. (1998). Ghana: revival of the mineral sector. Resources Policy, 24, 229-239.

Affaton, P., Rahaman, M.A., Trompette, R. and Sougy, J. (1991). The Dahomeyide orogeny: tectonothermal evolution and relationships with the Volta Basin. In: Dallmeyer, R.D. and Lécorché, J.P. (Eds), The West African Orogens and CircumAtlantic Correlatives, Springer-Verlag, New York, 107-122.

Allibone, A.H., McCuaig, T.C., Harris, D., Etheridge, M.A., Munroe, S., Byrne, D., Amanor, J. and Gyapong, W. (2002a). Structural controls on gold mineralization at the Ashanti gold deposit, Obuasi, Ghana, Society of Economic Geologists Special Publication 9, 65-93.

Allibone, A., Teasdale, J., Cameron, G., Etheridge, M., Uttley, P., Soboh, A., Appiah-Kubi, J., Adanu, A., Arthur, R., Mamphey, J., Odoom, B., Zuta, J., Tsikata, A., Pataye, F., Famiyeh, S. and Lamb, E. (2002b). Timing and structural controls on gold mineralization at the Bogoso Gold Mine, Ghana, West Africa. Economic Geology, 97, 949-969.

Amponsah, P.O., Salvi, S., Béziat, D., Baratoux, L., Siebenaller, L., Nude, P.M., Nyarko, R.S. and Jessell, M.W. (2015a). The Bepkong gold deposit, Northwestern Ghana. Ore Geology Reviews, http:/ /dx.doi.org/10.1016/j.oregeorev.2015.06.022.

Amponsah, P.O., Salvi, S., Béziat, D., Siebenaller, L., Baratoux, L. and Jessell, M.W. (2015b). Geology and geochemistry of the shear-hosted Julie gold deposit, NW Ghana. Journal of African Earth Sciences, http://dx.doi.org/10.1016/j.jafrearsci.2015.06. 013.

Anglogold Ashanti (2014). Integrated Annual Report 2014. www.anglogoldashanti.com.

Anonymous (2015). Groundbreaking partnership to revive Obuasi Gold Mine. http://www.randgoldresources.com/groundbreakingpartnership-revive-obuasi-gold-mine. Last accessed 20 October 2015.

Arhin, E. (2013). Use of regolith geochemistry to delineate gold mineralization under cover: A case study in the Lawra Belt, NW Ghana. Unpublished PhD thesis, University of Leicester, 257pp.

Aryee, B.N.A. (2001). Ghana's mining sector: its contribution to the national economy. Resources Policy, 27, 61-75.

Attoh, K., Evans, M.J. and Bickford, M.E. (2006). Geochemistry of an ultramafic-rodingite rock association in the Paleoproterozoic Dixcove greenstone belt, southwestern Ghana. Journal of African Earth Sciences, 45, 333-346.

Barning, K. (Ed) (1990). Symposium on gold exploration in tropical rain forest belts of Southern Ghana, Minerals Commission, Accra, 200pp.

Berge, J. (2011). Paleoproterozoic, turbidite-hosted, gold deposits of the Ashanti gold belt (Ghana, West Africa): Comparitive analysis of turbidite-hosted gold deposits and an updated genetic model. Ore Geology Reviews, 39, 91-100.

Bermúdez-Lugo, O. (2004). The mineral industry of Ghana. In: U.S. Geological Survey Minerals Yearbook-2004, 20.1-20.5.

Bermúdez-Lugo, O. (2011). The mineral industry of Ghana. In: U.S. Geological Survey Minerals Yearbook-2011, 20.1-20.6. 
Block, S., Ganne, J., Baratoux, L., Zeh, L., Parra-Avila, A., Jessell, M., Ailleres, L. and Siebenaller, L. (2015). Petrological and geochronological constraints on lower rocks crust exhumation during Paleoproterozoic (Eburnean) orogeny, NW Ghana, West African Craton. Journal of Metamorphic Geology, 33, 463-494.

Bowell, R.J. (1992). Supergene gold mineralogy at Ashanti, Ghana: Implications for the supergene behaviour of gold. Mineralogical Magazine, 56, 545-560.

Carranza, E.J.M., Owusu, E.A. amd Hale, M. (2009). Mapping of prospectivity and estimation of number of undiscovered prospects for lode gold, southwestern Ashanti Belt, Ghana. Mineralium Deposita, 44, 915-938.

Dampare, S.B., Shibata, T., Asiedu, D.K., Osae, S. and BanoengYakubo, B. (2008). Geochemistry of Paleoproterozoic metavolcanic rocks from the southern Ashanti volcanic belt, Ghana: Petrogenetic and tectonic setting implications. Precambrian Research, 162, 403-423.

Davis, D.W., Hirdes, W., Schaltegger, E. and Nunnoo, E.A. (1994). $\mathrm{U}-\mathrm{Pb}$ age constraints on deposition and provenance of Birimian and gold-bearing Tarkwaian sediments in Ghana, West Africa. Precambrian Research, 67, 89-107.

Eisenlohr, B.N. and Hirdes, W. (1992). Structural development of the early Proterozoic Birimian and Tarkwaian rocks of southwest Ghana, West Africa. Journal of African Earth Sciences, 14, 313325.

Ellis, A.B. (1893). A History of the Gold Coast of West Africa, Chapman and Hall, London, 400pp.

Ghana Chamber of Mines (2013). Performance of the mining industry in 2013, 10pp. Available at ghanachamberofmines.org/media/ publications.

Els, B.G. (1991). Placer formation during progradational fluvial degredation: the late Archean Middelvlei gold placer, Witwatersrand, South Africa. Economic Geology, 86, 261-277.

Endeavour Mining (2015). Website: http://www.endeavourmining. com/s/Nzema.asp. Last accessed 26 August 2015.

Ennih, N. and Liégeois, J.-P. (2008). The boundaries of the West African craton, with special reference to the basement of the Moroccan metacratonic Anti-Atlas belt. In: Ennih, N. and Liégeois, J.-P. (Eds), The Boundaries of the West African Craton, Geological Society, London, Special Publications, 297, 1-17.

Feybesse, J.-L., Billa, M., Guerrot, C., Duguey, E., Lescuyer, J.-L., Milesi, J.-P. and Bouchot, V. (2006). The Paleoproterozoic Ghanaian province: Geodynamic model and ore controls, including regional stress modeling. Precambrian Research, 149, 149-196.

Fougerouse, D., Micklethwaite, S., Miller, J., McCuaig, T.C. and Ulrich, S. (2013). Multistage mineralization of the giant Obuasi gold deposit, Ghana. In: Mineral Deposit Research for a HighTech World, 12th SGA Biennial Meeting 2013, Proceedings volume 3, 1105-1108

Fougerouse, D., Micklethwaite, S., Miller, J., Ulrich, S. and McCuaig, T.C. (2015). The Obuasi gold deposit, Ghana: A West African giant. Ore Geology Reviews, http://dx.doi.org/10.1016/ j.oregeorev.2015.06.019.

Frimmel, H.E. and Minter, W.E.L. (2002). Recent developments concerning the geological history and genesis of the Witwatersrand gold deposits, South Africa. In: Goldfarb, R.J. and Nielsen, R.L. (Eds.), Integrated Methods for Discovery: Global Exploration in the Twenty-First Century, Society of Economic Geologists, Littleton, Special Publication vol. 9, 17-45.

Ghana Chamber of Mines (2014). Report on the performance of the mining industry (2014), 22pp. Available at ghanachamberof mines.org/media/publications.

Ghana Chamber of Mines (GCM) and the International Council on
Mining \&Metals (ICMM) (2015). Mining in Ghana - What future can we expect? Report published jointly by the GCM and ICMM, Accra and London, 70pp. Available from www.icmm.com.

Gold Fields Limited (2015). Annual Report 2014. www.goldfields. co.za.

Golden Star Resources (2015). Website: http://www.gsr.com/ operations/reserves-and-resources/default.aspx. Last accessed 26 August 2015.

Griffis, R.J. (1998). Explanatory notes - geological interpretation of geophysical data from southwestern Ghana, Minerals Commission, Accra, 51pp.

Griffis, R.J. and Agezo, F.L. (2000). Mineral Occurrences and Exploration Potential of Northern Ghana, Minerals Commission Report, Accra, 132pp.

Griffis, R.J., Barning, K., Agezo, F.L. and Akosah, F.K. (2002). Gold deposits of Ghana, Minerals Commission, Accra, 432pp.

Hayward, C.L., Reimold, W.U., Gibson, R.L. and Robb, L.J. (2005). Gold mineralization within the Witwatersrand Basin, South Africa: evidence for a modified placer origin, and the role of the Vredefort impact event. In: McDonald, I., Boyce, A.J., Herrington, R.J. and Polya, D.A. (Eds.), Mineral Deposits and Earth Evolution, Geological Society, London, Special Publications, 248, 31-58.

Hilson, G. (2002). Harvesting mineral riches: 1000 years of gold mining in Ghana. Resources Policy, 28, 13-26.

Hirdes, W. and Nunoo, B. (1994). The Proterozoic paleoplacers at Tarkwa Gold Mine, SW Ghana: sedimentology, mineralogy, and precise age dating of the main reef and west reef, and bearing of the investigations on source area aspects. Geologische Jahrbuch, Reihe D, 100, 247-311.

Hirdes, W., Davis, D.W. and Eisenlohr, B.N. (1992). Reassessment of Proterozoic granitoid ages in Ghana on the basis of $\mathrm{U} / \mathrm{Pb}$ zircon and monazite dating. Precambrian Research, 56, 89-96.

Hirdes, W., Senger, R., Adjei, J., Efa, E., Loh, G. and Tettey, A. (1993). Explanatory notes for the geological map of southwest Ghana 1:100,000 (Wiawso, Asafo, Kukuom, Sunyani and Berekum sheets). Geologische Jahrbuch, Reihe B, 83, 139pp.

Hoffman, P.F. (1999). The break-up of Rodinia, birth of Gondwana, true polar wander and the snowball Earth. Journal of African Earth Sciences, 28, 17-33.

Höhndorf, A., Oberthür, T., Gast, L., Vetter, D. and Schmidt Mumm, A. (1994). Lead isotope systematics of the mineralisation at the Ashanti gold mine, Obuasi, Ghana. Geologische Jahrbuch, D100, 155-166.

Illife, J. (1995). Africans - The History of a Continent, Cambridge University Press, Cambridge, 323pp.

John, T., Klemd, R., Hirdes, W. and Loh, G. (1999). The metamorphic evolution of the Paleoproterozoic (Birimian) volcanic Ashanti Belt (Ghana, West Africa). Precambrian Research, 98, 11-30.

Junner, N.R. (1935). Gold in the Gold Coast, Gold Coast Geological Survey Memorandum no. 4, Accra, 67pp.

Junner, N.R. (1940). Geology of the Gold Coast and Western Togoland with Revised Geological Map, Gold Coast Geological Survey Bulletin no. 11, Accra, 40pp.

Junner, N.R., Hirst, T. and Service, H. (1942). The Tarkwa Goldfield. Gold Coast Geological Survey Memoirs, 4, 75pp.

Kenworthy, S., Noormohamed, K., Stuart, H. and Hodkiewicz, P. (2000). Mapping and 3D modelling of structural controls in the Chorano gold deposits, Ghana: keys to better resource delineation and near-mine exploration targettiing. Proceedings of the Seventh International Mining Geology Conference 2009, The Australian Institute of Mining and Metallurgy, Melbourne, 101-108.

Kesse, G.O. (1984). The occurrence of gold in Ghana. In: Foster, R.P. (Ed), Gold '82: The geology, geochemistry and genesis of 
gold deposits, Balkema, Rotterdam, 645-659.

Kesse, G.O. (1985). The Mineral and Rock Resources of Ghana, Ballkema Publishers, Rotterdam, 610pp.

Kesse, G.O. (1990). An overview of gold resources in Ghana. In: Barning, K. (Ed.), Symposium on gold exploration in tropical rain forest belts of southern Ghana, Minerals Commission, Accra, 3-11.

Kiessling, R. (1997). Sedimentation and structure in the Tarkwaian Group of the Bui Basin in West-Ghana. In: Zitzmann (Ed), Geological, Geophysical and Geochemical Investigations in the Bui Belt Area in Ghana, Geologische Jahrbuch, Reihe B, 88, 269pp.

Kinross Gold Corporation (2015). Website: http://www.kinross.com/ operations/operation-chirano-ghana.aspx. Last accessed 26 August 2015.

Klemd, R., Hirdes, W., Olesch, M. and Oberthür, T. (1993). Fluid inclusions in quartz-pebbles of the gold-bearing Tarkwaian conglomerates of Ghana as guides to their provenance area. Mineralium Deposita, 28, 334-343.

Kuma, J.S., Kim, Y.U., Boamah, D. and Sakamoto, I. (2010). Gold potential of the Ashanti Belt of Ghana. Journal of The School of Marine Science and Technology, Tokai University, 8, 25-39.

Kwang, C., Ossei, E.M. Jnr. and Duker, A.A. (2014). Application of remote sensing and geographic information systems for gold potential mapping in Birim North District of eastern region of Ghana. International Journal of Remote Sensing Applications, 4, 48-55.

Leube, A., Hirdes, W., Mauer, R. and Kesse, G.O. (1990). The early Proterozoic Birimian Supergroup of Ghana and some aspects of its associated gold mineralization. Precambrian Research, 46, 139165.

Loh, G., Hirdes, W., Anani, C., Davis, D.W. and Vetter, U. (1999). Explanatory notes for the geological map of southwest Ghana 1:100,000. Geologische Jahrbuch, Reihe B, 93, 150pp.

Magalhães, L.A. and Filho, C.R.S. (2012). Targeting of gold deposits in Amazonian exploration frontiers using knowledge- and datadriven spatial modeling of geophysical, geochemical and geological data. Surveys in Geophysics, 33, 211-241.

Manu, J., Hayford, E.K., Anani, C., Sakyi, P.A., Kutu, J.M. and Armah, T.E.K. (2013). Aspects of the chemical composition of the Birimian gold fluid. Journal of Earth Sciences and Geotechnical Engineering, 3, 87-106.

Milési, J.P., Ledru, P., Ankrah, P., Johan, V., Marcoux, E. and Vinchon, Ch. (1991). The metallogenic relationship between Birimian and Tarkwaian gold deposits in Ghana. Mineralium Deposita, 26, 228-238.

Milési, J.P., Ledru, P., Feybesse, J.L., Dommanget, A. and Marcoux, E. (1992). Early Proterozoic ore deposits and tectonics of the Birimian orogenic belt, West Africa. Precambrian Research, 58, 305-344.

Mumin, A.H. and Fleet, M.E. (1995). Evolution of gold mineralization in the Ashanti Gold Belt, Ghana: evidence from carbonate compositions and parageneses. Mineralogy and Petrology, 55, 265-280.

Mumin, A.H., Fleet, M.E. and Chryssoulis, S.L. (1994). Gold mineralization in As-rich mesothermal gold ores of the BogosuPrestea mining disctrict of the Ashanti Gold Belt, Ghana: remobilization of "invisible" gold. Mineralium Deposita, 29, 445-460.

Mumin, A.H., Fleet, M.E. and Longstaffe, F.J. (1996). Evolution of hydrothermal fluids in the Ashanti Gold Belt, Ghana: Stable isotope geochemistry of carbonates, graphite, and quartz. Economic Geology, 91, 135-148.
Nédélec, A., Affaton, P., Grance-Lanord, C., Charrière, A. and Alvaro, J. (2007). Sedimentology and chemostratigraphy of the Bwipe Neoproterozoic cap dolostones (Ghana, Volta Basin): A record of microbial activity in a peritidal environment. C.R. Geoscience, 339, 223-239.

Newmont (2015). Newmont Reserves and Resources as of December 31, 2014. Downloaded from: www.newmont.com/files/ doc_downloads/reserves_and_resources/Reserves-Resources-forPosting_Final.pdf on 26 August 2015.

Nude, P.M. and Arhin, E. (2009). Overbank sediments as appropriate geochemical sample media in regional stream sediment surveys for gold exploration in the savannah regions of northern Ghana. Journal of Geochemical Exploration, 103, 50-56.

Nyame, F.K. (2010). Policy challenges on mercury use in Ghana's artisanal and small-scale mining sector. International Journal of Environment and Pollution, 41, 202-213.

Nyame, F.K. (2013). Origins of Birimian (ca 2.2 Ga) mafic magmatism and the Paleoproterozoic 'greenstone belt' metallogeny: a review. Island Arc, 22, 538-548.

Nyame, F.K. and Blocher, J. (2010). Influence of land tenure practices on artisanal mining activity in Ghana. Resources Policy, 35, 47-53.

Nyame, F.K. and Grant, J.A. (2012). From carats to karats: explaining the shift from diamond to gold mining by artisanal miners in Ghana. Journal of Cleaner Production, 29-30, 163-172.

Nyame, F.K. and Grant, J.A. (2014). The political economy of transitory mining in Ghana: Understanding the trajectories, triumphs, and tribulations of artisanal and small-scale operators. The Extractive Industries and Society, 1, 75-85.

Oberthür, T., Vetter, U., Schmidt Mumm, A., Weiser, T., Amanor, J.A., Gyapong, W., Kumi, R. and Blenkinsop, T.G. (1994). The Ashanti gold mine at Obuasi, Ghana: Mineralogical, geochemical, stable isotope and fluid inclusion studies on the metallogenesis of the deposit. Geologisches Jahrbuch D, 100, 31-129.

Oberthür, T., Hirdes, W., Höhndorf, A., Schmidt Mumm, A., Vetter, U., Weiser, T., Davis, D.W., Blenkinsop, T.G., Amanor, J.A. and Loh, G. (1995). A review of gold mineralisation in the Ashanti Belt of Ghana and its relation to the crustal evolution of the terrane. Communications of the Geological Survey of Namibia, 10, 121127.

Oberthür, T., Weiser, T., Amanor, J.A. and Chryssoulis, S.L. (1997). Mineralogical siting and distribution of gold in quartz veins and sulfide ores of the Ashanti mine and other deposits in the Ashanti belt of Ghana: genetic implications. Mineralium Deposita, $32,2-15$.

Oberthür, T, Vetter, U., Davis, D.W. and Amanor, J.A. (1998). Age constraints on gold mineralization and Paleoproterozoic crustal evolution in the Ashanti belt of southern Ghana. Precambrian Research, 89, 129-143.

Owusu, E.A., Woldai, T., Barritt, S., Carranza, E.J.M. and Hale, M. (2006). Spacial association of gold deposits with remotely-sensed faults, south Ashanti Belt, Ghana. Conference: 6th AARSE international conference on earth observation and geoinformation sciences in support of Africa's development. Volume: ISBN 1920-01710-0. 8 p. Downloadable at: http://www.researchgate.net/ profile/Tsehaie_Woldai/publication/233791624_Spatial_ association_of_gold_deposits_with_remotely___sensed_faults_ South_Ashanti_belt_Ghana/links/0deec5252 acd1584750 00000.pdf.

Parra-Avila, L.A., Bourassa, Y., Miller, J., Perrouty, S., Fiorentini, M.L. and McCuaig, T.C. (2015). Age constraints of the Wassa and Benso Mesothermal Gold Deposits, Ashanti Belt, Ghana, West Africa. Journal of African Earth Sciences, http://dx.doi.org/ 10.1016/j.jafrearsci.2015.05.017. 
Perrouty, S., Aillères, L., Jessell, M.W., Baratoux, L., Bourassa, Y. and Crawford, B. (2012). Revised Eburnean geodynamic evolution of the gold-rich southern Ashanti Belt, Ghana, with new field and geophysical evidence of pre-Tarkwaian deformations. Precambrian Research, 204-205, 12-39.

Perrouty, S., Lindsay, M.D., Jessell, M.W., Aillères, L., Martin, R. and Bourassa, Y. (2014). 3D modeling of the Ashanti Belt, southwest Ghana: Evidence for a litho-stratigraphic control on gold occurrences within the Birimian Sefwi Group. Ore Geology Reviews, 63, 252-264.

Perrouty, S., Jessell, M.W., Bourassa, Y., Miller, J., Apau, D., Siebenaller, L., Velásquez, G., Baratoux, L., Aillères, L., Béziat, D. and Salvi, S. (2015). The Wassa deposit: A poly-deformed orogenic gold system in southwest Ghana - Implications for regional exploration. Journal of African Earth Sciences, http:// dx.doi.org/10.1016/j.jafrearsci.2015.03.003.

Perseus Mining Limited (2015). Website: http://www.perseusmining. com.au/reserves_and resources.66.html. Last accessed 26 August 2015.

Petters, S.W. (1991). Regional Geology of Africa, Springer-Verlag, Berlin, 722pp.

Pigois, J.-P., Groves, D.I., Fletcher, I.R., McNaughton, N.J. and Snee, L.W. (2003). Age constraints on Tarkwaian palaeoplacer and lodegold formation in the Tarkwa-Damang district, SW Ghana. Mineralium Deposita, 38, 695-714.

Porter, S.M., Knoll, A.H. and Affaton, P. (2004). Chemostratigraphy of Neoproterozoic cap carbonates from the Volta Basin, West Africa. Precambrian Research, 130, 99-112.

Porwal, A. and Carannza, E.J.M. (2015). Introduction to the Special Issue: GIS-based mineral potential modelling and geological data analyses for mineral exploration. Ore Geology Reviews, 71, 477483.

Robb, L.J. (2005). Introduction to Ore-forming Processes, Blackwell, Malden, 373pp.

Robb, L.J., Charlesworth, E.G., Drennan, G.R., Gibson, R.L. and Tongu, E.L. (1997). Tectono-metamorphic setting of the paragenetic sequence of the Au-U mineralisation in the Archaean Witwatersrand Basin, South Africa. Australian Journal of Earth Sciences, 44, 353-371.

Robert, F., Brommecker, R., Bourne, B.T., Dobak, P.J., McEwan, C.J., Rowe, R.R. and Zhou, X. (2007). Models and explorations methods for major gold deposit types. In: Milkereit, B. (Ed), Proceedings of Exploration 07: Fifth Decennial International Conference on Mineral Exploration, Decennial Mineral Exploration Conferences, Toronto, 691-711.

Sestini, G. (1973). Sedimentology of a paleoplacer: the gold bearing Tarkwaian of Ghana. In: Amstutz, G.C. and Bernard A.J. (Eds), Ores in Sediments, Springer-Verlag, Heidelberg, 275303.

Sibson, R.H., Moore, J. McM. and Rankin, A.H. (1975). Seismic pumping - a hydothermal fluid transport mechanism. Journal of the Geological Society of London, 131, 653-659.

Sibson, R.H., Robert, F. and Poulsen, K.H. (1988). High-angle reverse faults, fluid-pressure cycling, and mesothermal gold-quartz deposits. Geology, 16, 551-555.

Stokes, R.S.G. (1908). Mines and Minerals of the British Empire, Edward Arnold, London, 403pp.

Strogen, P. (1991). The sedimentology, strarigraphy and structure of the Tarkwaian, western region, and its relevance to gold exploration and development. In: Kesse, G.O. (Ed), Proceedings of the International Conference on the Geology of Ghana, Geological Society of Ghana, Accra, 3, R1-R39.

Sylvester, P.J. and Attoh, K. (1992). Lithostratigraphy and composition of $2.1 \mathrm{Ga}$ greenstone belts of the West African craton and their bearing on crustal evolution and Archean-Proterozoic boundary. Journal of Geology, 100, 377-393.

Tsiboah, T. and Grant, T. (2009). Application of geophysics to gold explorations in Ghana: examples from Newmont projects. ASEG Extended Abstracts, 2001(1), 1-5. Full text doi:10.1071/ ASEG2009 ab089.

Tsikata, F.S. (1997). The vicissitudes of mineral policy in Ghana. Resources Policy, 1997, 9-14.

Tunks, A.J., Selley, D., Rogers, J.R. and Brabham, G. (2004). Vein mineralization at the Damang Gold Mine, Ghana: controls on mineralization. Journal of Structural Geology, 26, 1257-1273.

Ward, W.E.F. (1967). A History of Ghana $\left(4^{\text {th }}\right.$ ed), George Allen and Unwin, London, 454pp.

Wemegah, D.D., Preko, K., Noye, R.M., Boadi, B., Menyeh, A., Danuor, K. and Amenyoh, T. (2015). Geophysical interpretation of possible gold mineralization zones in Kyerano, south-western Ghana using aeromagnetic and radiometric datasets. Journal of Geosciences and Environmental Protections, 3, 67-82.

Wright, J.B., Hastings, D.A. and Jones, W.B. (1985). Geology and Mineral Resources of West Africa, G. Allen and Unwin, London, $187 \mathrm{pp}$.

Yao, Y. and Robb, L.J. (1998). The Birimian granitoids of Ghana: A review. Economic Geology Research Unit (EGRU), University of Witwatersrand, Information Circular 322, 46pp.

Yao, Y. and Robb, L.J. (1999). Gold mineralization associated with Birimian granitoids of Ghana. Final report to Goldfields of South Africa (unpubl.), University of Witwatersrand, Johannesburg, 247pp.

Yao, Y. and Robb, L.J. (2000). Gold mineralization in Paleoproterozoic granitoids at Obuasi, Ashanti region, Ghana: Ore geology, geochemistry and fluid characteristics. South African Journal of Geology, 103, 255-278.

Yao, Y., Murphy, P.J. and Robb, L.J. (2001). Fluid characteristics of granitoid-hosted gold deposits in the Birimian Terrane of Ghana: A fluid inclusion microthermometric and Raman spectroscopic study. Economic Geology, 96, 1611-1643. 


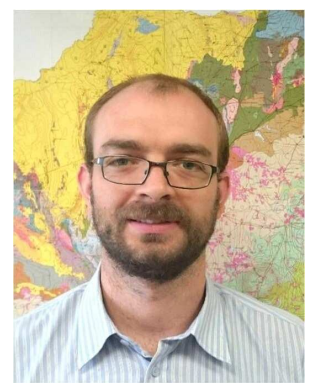

Bertus Smith is a senior lecturer in the Department of Geology at the University of Johannesburg where he has been teaching and researching full-time since 2008. He is also involved as a researcher and student supervisor with the PPM Research Group and the South African Department of Science and Technology - National Research Foundation's Centre of Excellence for Integrated Mineral and Energy Resources Analysis (DST-NRF CIMERA) at the University of Johannesburg. His main research interests are economic geology, early Earth surface paleoenvironments and process mineralogy.

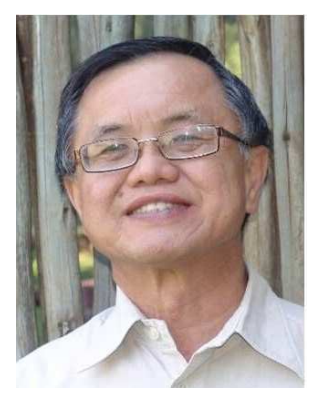

George Henry is the Administrative Manager of the South African Department of Science and Technology - National Research Foundation's Centre of Excellence for Integrated Mineral and Energy Resources Analysis (DST-NRF CIMERA) hosted at the University of Johannesburg and co-hosted at the University of the Witwatersrand. He has had a varied career in both industry and academia, having worked for Randgold Resources after doctoral graduation, the Council for Geoscience, and the Council for Industrial and Scientific Research, amongst others. He is interested in economic and exploration geology, and the origin of mineral deposits.

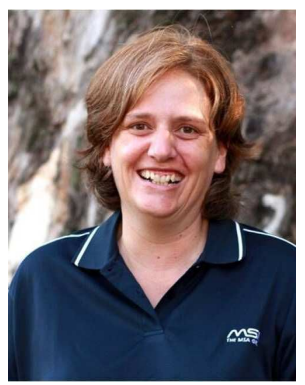

Susan Frost-Killian is a senior research geologist with The MSA Group (Pty) Ltd in Johannesburg, South Africa. She has almost twenty years professional experience covering: commodity, geological, and country research; metallogenic and prospectivity mapping; GIS; mineral assessments; technical editing and providing assistance with the compilation and submission of Competent Persons Mineral Resource Estimates, Scoping and PreFeasibility technical reports and due diligence reviews. Her experience covers regional and country specific projects in Africa, collaborative projects with African geological surveys, India, the United States, and some countries within the European Union, and country reports (minerals, geology, etc.) for various countries (global). 